\title{
\#USGS
}

science for a changing world

Prepared in cooperation with Clean Water Services

\section{Reconnaissance of Pharmaceutical Chemicals in Urban Streams of the Tualatin River Basin, Oregon, 2002}
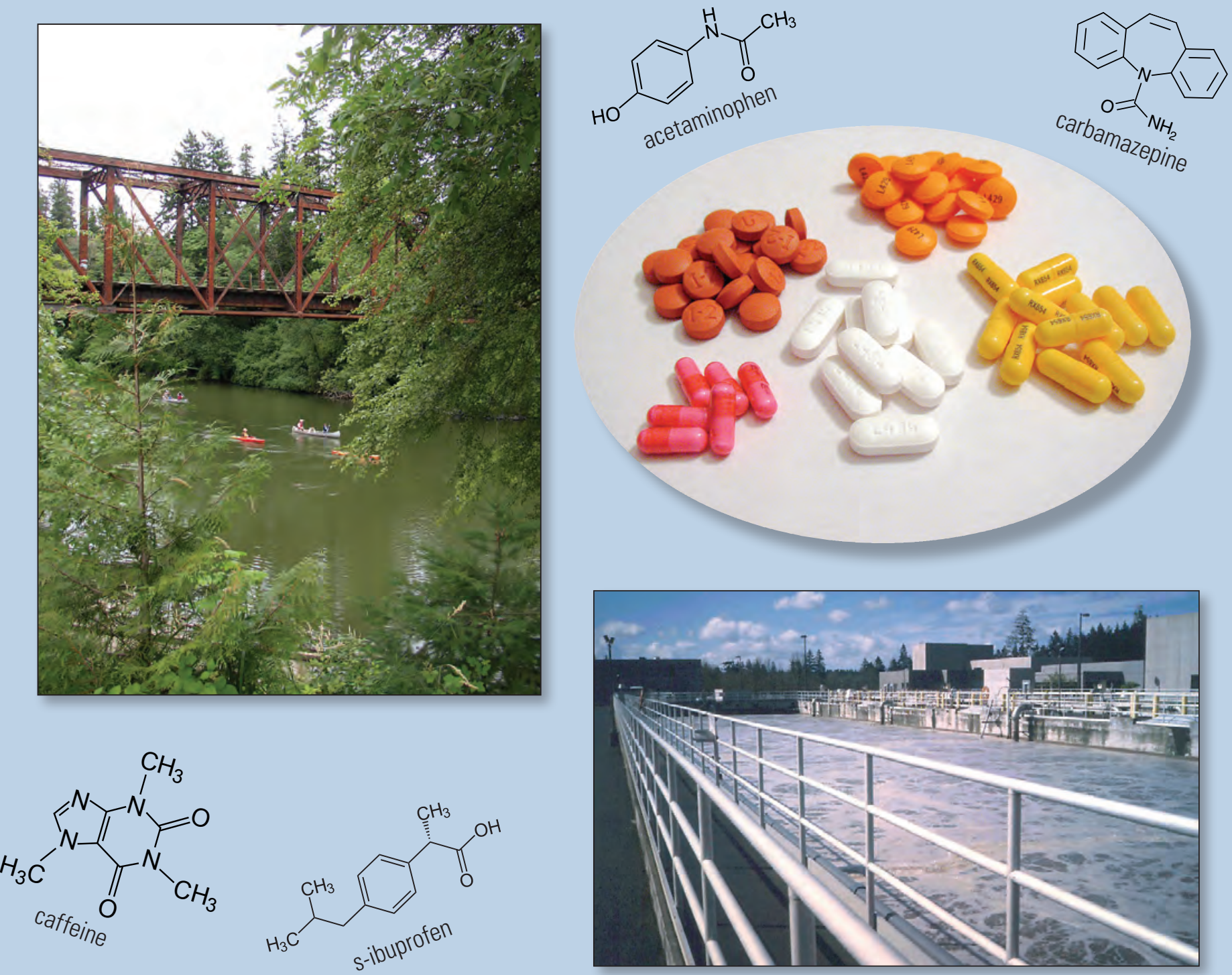

Scientific Investigations Report 2009-5119

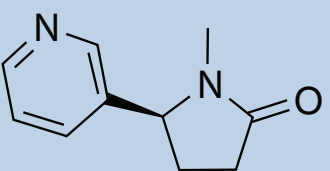

cotinine 


\section{Front Cover:}

Top left: Tualatin River at Tualatin City Park, Oregon, July 19, 2008.

Top right: Common preparations of over-the-counter and prescription pharmaceutical chemicals

Bottom right: Treatment basin at Clean Water Service's Rock Creek Wastewater Treatment Facility, Hillsboro, Oregon, 1998.

\section{Back Cover:}

Top left: Photograph of Fanno Creek at 56th Avenue, Portland, Oregon, April 8, 2003.

Bottom left: Photograph of Fanno Creek at Scholls Ferry, near Allen Blvd., Portland, Oregon, April 8, 2003.

Right: Photograph of Fanno Creek downstream of footbridge in Durham City Park, Oregon, April 6, 2003.

All photographs by Stewart Rounds, U.S. Geological Survey. 


\section{Reconnaissance of Pharmaceutical Chemicals in Urban Streams of the Tualatin River Basin, Oregon, 2002}

By Stewart A. Rounds and Micelis C. Doyle, U.S. Geological Survey; Patrick M. Edwards, Portland State University; and Edward T. Furlong, U.S. Geological Survey

Prepared in cooperation with Clean Water Services

Scientific Investigations Report 2009-5119 


\title{
U.S. Department of the Interior \\ KEN SALAZAR, Secretary \\ U.S. Geological Survey \\ Suzette M. Kimball, Acting Director
}

\section{U.S. Geological Survey, Reston, Virginia: 2009}

\author{
For more information on the USGS - the Federal source for science about the Earth, its natural and living resources, \\ natural hazards, and the environment, visit http://www.usgs.gov or call 1-888-ASK-USGS \\ For an overview of USGS information products, including maps, imagery, and publications, \\ visit http://www.usgs.gov/pubprod \\ To order this and other USGS information products, visit http://store.usgs.gov
}

Any use of trade, product, or firm names is for descriptive purposes only and does not imply endorsement by the U.S. Government.

Although this report is in the public domain, permission must be secured from the individual copyright owners to reproduce any copyrighted materials contained within this report.

Suggested citation:

Rounds, S.A., Doyle, M.C., Edwards, P.M., and Furlong, E.T., 2009, Reconnaissance of pharmaceutical chemicals in urban streams of the Tualatin River basin, Oregon, 2002: U.S. Geological Survey Scientific Investigations Report 2009-5119, 22 p. 


\section{Contents}

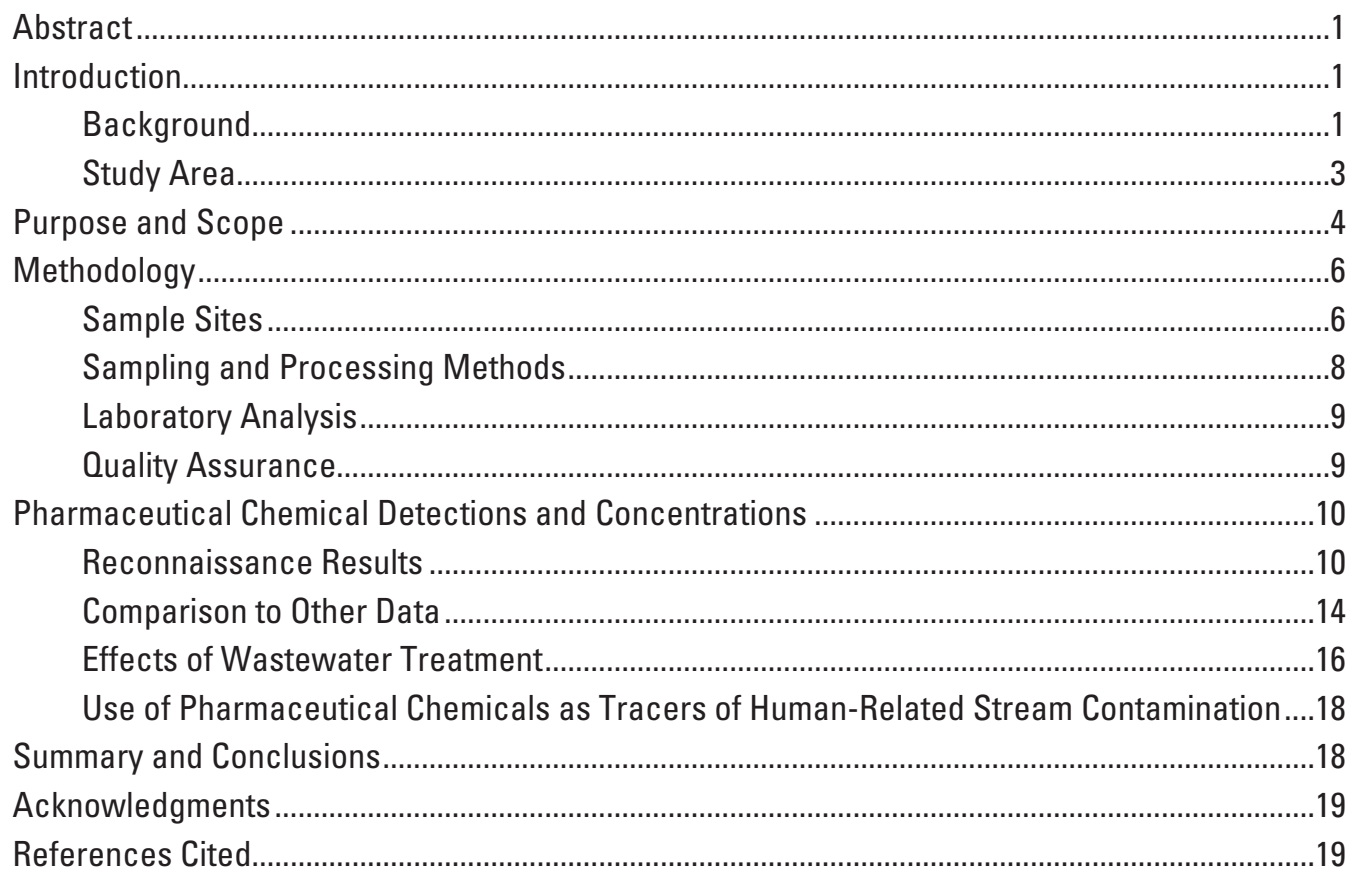

\section{Figures}

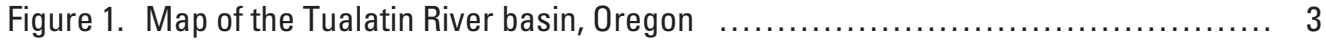

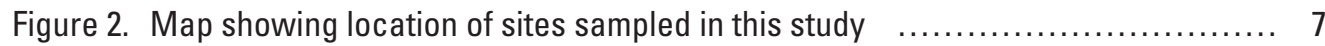

Figure 3. Schematic diagram of summertime treatment processes at Clean Water Services' Durham wastewater treatment facility in $2002 \ldots \ldots \ldots \ldots \ldots \ldots \ldots \ldots \ldots . \quad 8$

Figure 4. Boxplot showing concentrations of pharmaceuticals and metabolites detected in stream and river samples in this study and instream concentrations from a 1999-2000 national study

\section{Tables}

Table 1. Pharmaceutical chemicals and metabolites included in this study $\ldots \ldots \ldots \ldots \ldots \ldots$

Table 2. Samples collected for pharmaceutical chemical analysis in the Tualatin River basin, Oregon, 2002

Table 3. Results of quality control analyses for pharmaceutical chemicals included in

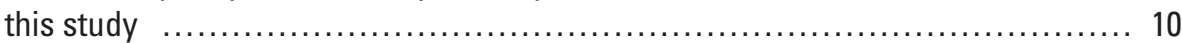

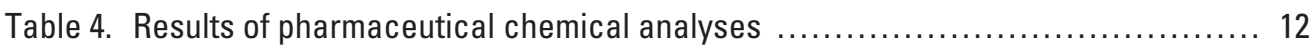

Table 5. Detection frequency for pharmaceutical chemicals analyzed in this study ....... 14

Table 6. Apparent removal rates of pharmaceutical compounds from wastewater by the Durham WWTF 


\section{Conversion Factors, Datums, and Acronyms}

Conversion Factors

Inch/Pound to SI

\begin{tabular}{lcl}
\hline \multicolumn{1}{c}{ Multiply } & By & \multicolumn{1}{c}{ To obtain } \\
\hline cubic foot per second $\left(\mathrm{ft}^{3} / \mathrm{s}\right)$ & 0.02832 & cubic meter per second $\left(\mathrm{m}^{3} / \mathrm{s}\right)$ \\
gallon (gal) & 0.003785 & cubic meter $\left(\mathrm{m}^{3}\right)$ \\
mile (mi) & 1.609 & kilometer $(\mathrm{km})$ \\
million gallons (Mgal) & 3,785 & cubic meter $\left(\mathrm{m}^{3}\right)$ \\
million gallons per day $(\mathrm{Mgal} / \mathrm{d})$ & 0.04381 & cubic meter per second $\left(\mathrm{m}^{3} / \mathrm{s}\right)$ \\
ounce, fluid (fl. oz) & 0.02957 & liter $(\mathrm{L})$ \\
\hline
\end{tabular}

SI to Inch/Pound

\begin{tabular}{lll}
\hline \multicolumn{1}{c}{ Multiply } & \multicolumn{1}{c}{ By } & \multicolumn{1}{c}{ To obtain } \\
\hline centimeter $(\mathrm{cm})$ & 0.3937 & inch (in) \\
kilogram $(\mathrm{kg})$ & 2.205 & pound avoirdupois (lb) \\
liter $(\mathrm{L})$ & 33.82 & ounce, fluid (fl. oz) \\
\hline
\end{tabular}

Temperature in degrees Celsius $\left({ }^{\circ} \mathrm{C}\right)$ may be converted to degrees Fahrenheit $\left({ }^{\circ} \mathrm{F}\right)$ as follows:

$$
{ }^{\circ} \mathrm{F}=\left(1.8 x^{\circ} \mathrm{C}\right)+32 \text {. }
$$

Concentrations of chemical constituents in water are given either in milligrams per liter (mg/L) or micrograms per liter $(\mu \mathrm{g} / \mathrm{L})$. Concentrations of chemical constituents in sediment are given in nanograms per gram $(\mathrm{ng} / \mathrm{g})$.

Datums

Vertical coordinate information is referenced to the North American Vertical Datum of 1988 (NAVD 88).

Horizontal coordinate information is referenced to the North American Datum of 1983 (NAD 83).

\section{Acronyms}

ESI

EWI

HPLC

LC50

MS

NWQL

SPE

USGS

WWTF electrospray ionization

equal-width increment

high-performance liquid chromatography

concentration lethal to 50 percent of test organisms

mass spectrometer

National Water Quality Laboratory

solid phase extraction

U.S. Geological Survey

wastewater treatment facility 


\title{
Reconnaissance of Pharmaceutical Chemicals in Urban Streams of the Tualatin River Basin, Oregon, 2002
}

\author{
By Stewart A. Rounds and Micelis C. Doyle, U.S. Geological Survey; Patrick M. Edwards, Portland State \\ University; and Edward T. Furlong, U.S. Geological Survey
}

\section{Abstract}

A reconnaissance of pharmaceutical chemicals in urban streams of the Tualatin River basin was conducted in July 2002 in an effort to better understand the occurrence and distribution of such compounds, and to determine whether they might be useful indicators of human-related stream contamination. Of the 21 pharmaceutical chemicals and metabolites tested, only 6 (acetaminophen, caffeine, carbamazepine, codeine, cotinine, and sulfamethoxazole) were detected in filtered stream samples from 10 sites. The concentrations of most of the detected compounds were relatively low (less than 0.05 microgram per liter). The most frequently detected compounds were cotinine (a nicotine metabolite, 8 of 10 samples) and caffeine (a stimulant, 7 of 10 samples). More compounds were detected in urban stream samples than in samples from forested or agricultural drainages.

Filtered water samples also were collected from four locations within an advanced wastewater treatment facility to quantify the relative amounts of these chemicals in a municipal waste stream and to determine the degree to which those chemicals are removed by treatment processes. Fifteen pharmaceutical chemicals or metabolites were detected in wastewater treatment facility influent, with concentrations far exceeding those measured in streams. Only five of those compounds, however, were detected in the treated effluent (carbamazepine, cotinine, ibuprofen, metformin, and sulfamethoxazole) and most of those were at concentrations less than 0.2 microgram per liter.

The target pharmaceutical chemicals and metabolites showed limited potential for use as tracers of specific types of human-related contamination in Tualatin River basin streams because of widespread sources (caffeine, for example) or extremely low concentrations. Caffeine and cotinine are likely to be good indicators of sources that can occur in urban areas, such as sewage spills or leaks or the widespread use and careless disposal of tobacco products and caffeinecontaining beverages. Neither compound, however, is likely to be a good tracer for a specific source unless that source is large. The presence of 1,7-dimethylxanthine (a caffeine metabolite) concurrently with caffeine might indicate the presence of untreated wastewater; in contrast, the absence of the metabolite might help rule out that source. Acetaminophen might make a good tracer for untreated wastewater because of its common usage, high concentration in raw wastewater, and effective removal via treatment. Carbamazepine and sulfamethoxazole have the potential to be good indicators of treated wastewater because of their incomplete removal in treatment facilities. Some of these pharmaceutical chemicals, either singly or in combination, might prove useful as tracers of contamination after further study.

\section{Introduction}

\section{Background}

Modern pharmacologic research since the middle of the 19th century has resulted in the development or discovery of numerous drugs for the treatment of disease and the relief of ailments. The numbers and types of these drugs, or pharmaceutical chemicals, and the amounts used, have increased greatly in the last several decades, to the point where thousands of drugs are used today. Many are in common or daily use in the world's developed countries (Kaufman and others, 2002). Increased use can lead to increased concentrations in waste streams and the potential for release of ever larger loads of these compounds to the environment. Prior to the last 10 years, few studies had been performed to determine the sources, transport, and fate of such compounds. An array of published studies now are available showing that pharmaceutical chemicals and their metabolites are present in streams at a wide range of concentrations, particularly downstream of human population centers (Halling-Sørensen and others, 1998; Daughton and Ternes, 1999). Researchers have investigated the occurrence of pharmaceuticals in surface waters (Buser and others, 1998; Kolpin and others, 
2002; Calamari and others, 2003; Löffler and others, 2005) and groundwater (Seiler and others, 1999; Hinkle and others, 2005; Barnes and others, 2008), the presence of such compounds in and their removal from wastewater (Ternes, 1998; Ternes and others, 2004; Jones and others, 2005), and the ecological effects of these compounds (Wilson and others, 2003; Gagné and others, 2006; Kim and others, 2007).

Despite these research efforts, few data exist to quantify the occurrence, concentration, and likely ecological effects of pharmaceutical chemicals in surface waters. A national reconnaissance was carried out in 1999-2000 by the U.S. Geological Survey (USGS) to assess the presence and concentrations of a suite of pharmaceuticals and other compounds in 139 streams across the United States (Kolpin and others, 2002). That study provides a good framework and baseline for developing a better understanding of the occurrence of pharmaceuticals and their metabolites in the Nation's streams, but was not designed to determine the occurrence and effects of these compounds on a local scale; for example, only three water samples from Oregon were analyzed as part of that study. Given a growing and aging population with increased reliance on pharmaceuticals for the treatment of medical conditions, increased use of pharmaceuticals in agriculture, and greater public interest in the quality of drinking water and the health of aquatic species, the need to learn more about the occurrence and concentrations of pharmaceutical chemicals in Oregon's streams is becoming increasingly important.

Some important source pathways of pharmaceutical chemicals, such as wastewater treatment facilities (WWTFs, which receive waste from hospitals, households, and municipal industries), have been identified in previous studies and need to be considered and assessed locally. Ternes (1998) was one of the first to document the presence of pharmaceuticals in raw and treated wastewater, using samples from selected WWTFs in Germany. Most modern WWTFs were not designed specifically to remove pharmaceutical chemicals from the waste stream. Many such chemicals are removed fairly efficiently through standard wastewater treatment, but others are not. Even if a large fraction of a pharmaceutical is removed through treatment, the remaining load still may constitute a large source to the receiving water body. Similar conclusions were reached in other studies in which higher concentrations of pharmaceuticals were measured downstream of WWTFs or population centers (Buerge and others, 2003; Kolpin and others, 2004; Glassmeyer and others, 2005; Gagné and others, 2006; Han and others, 2006; Karthikeyan and Meyer, 2006; Wilkison and others, 2006; Guo and Krasner, 2009). Research by Bedner and MacCrehan (2006) suggested that the chlorination process used in some WWTFs might transform acetaminophen, a common analgesic and one of the most widely used pharmaceutical chemicals, into a more harmful form. It is not just the parent pharmaceuticals, therefore, but their metabolites and degradates that must be studied to better understand the full effect of pharmaceuticals in the environment.

The potential for ecological effects caused by the presence of pharmaceuticals and their metabolites in aquatic systems is poorly understood at this time (2009). Because these compounds inherently affect physiological processes, it is likely that a measurable and potentially harmful ecological effect could occur at some concentration, but more research is necessary to define the ecological risks. Gagné and others (2006), for example, detected a wide range of pharmaceuticals in municipal treatment facility effluent and determined that such compounds have the potential to produce a toxic response in rainbow trout. Kim and others (2007) examined the toxicity of four widely used pharmaceuticals and six sulfonamide antibiotics and determined that several might have acutely toxic effects at concentrations greater than $1 \mathrm{mg} / \mathrm{L}$ and that some potential ecological risk is present at lower concentrations. Han and others (2006) assessed the ecotoxicological effect of a handful of pharmaceuticals on a common plankton species, determined that toxic effects can occur at sufficiently high concentrations, and found that although typical pharmaceutical concentrations downstream of certain WWTFs did not result in a significant risk, the potential for significant risk did exist. The ecological effects of pharmaceuticals in the environment is a subject with many unexplored topics such as synergistic effects, the risks of chronic and multiple-year exposure to trace concentrations, and the risks resulting from pharmaceutical metabolites and degradates.

In addition to WWTF sources, pharmaceuticals and other biological and chemical contaminants can enter surface waters through accidental or illicit dumping, poorly managed or failing on-site or septic systems, storm-sewer/ sanitary-sewer cross connections, and unmanaged pet and animal wastes, among other sources. Proactive management and protection of aquatic resources would greatly benefit from the development of one or more definitive methods of identifying and tracking these separate sources. A wide variety of techniques and tracers are being developed in response to this need. Genetic techniques, for example, are becoming increasingly useful in identifying the sources of bacteria detected in streams (Stoeckel and others, 2004). Chemicals such as caffeine historically have proven useful as markers of human-related contaminant sources (Buerge and others, 2003), but that use may be diminishing because of the widespread consumption and careless disposal of caffeinated beverages. Other studies have found that, in addition to caffeine, certain anionic surfactants and fluorescent whitening agents (the "optical brighteners" in some laundry detergents) are good indicators associated with fecal coliform contamination (Sankararamakrishnan and Guo, 2005). Standley and others (2000) found that certain fragrance compounds, in conjunction with caffeine, can be used as tracers of human-related 
contaminant sources. The identification of a suite of chemical markers that is unique to human-related sources of stream pollution would prove invaluable to investigations of contaminant fate and transport as well as the management of water resources.

Pharmaceutical chemicals represent a compound class with great potential for use as tracers of specific sources of anthropogenic pollution. For use as a tracer of human-related contamination, a candidate compound should have few or no natural sources, no normal means of entering the stream of interest, a well-defined usage pattern, a sufficiently long lifetime to allow detection in the environment, and a reliable and accurate means of detecting and quantifying its presence in water, sediment, or tissue samples. Many pharmaceutical chemicals fit this general profile, although it is unclear which candidate pharmaceuticals might make the best tracers for sources of human-related stream contamination.

\section{Study Area}

The Tualatin River basin in northwest Oregon includes the western edge of Portland (Oregon's largest city) and Portland's western suburbs and outlying communities. In 2002 , the basin was home to a rapidly growing human population of about 500,000 (U.S. Census Bureau, 2006). The great majority of those people live within a designated urban growth boundary which contains the cities of Portland, Beaverton, Tigard, Tualatin, Hillsboro, and Forest Grove, to name just a few (fig. 1). The cities are located primarily on the valley floor and are gathered mainly toward the middle and eastern edge of the basin. From its headwaters in the forested Coast Range mountains to the west, the Tualatin River meanders east through agricultural areas on the valley bottom before skirting the southern edge of the urban area and joining the Willamette River south (upstream) of Portland.

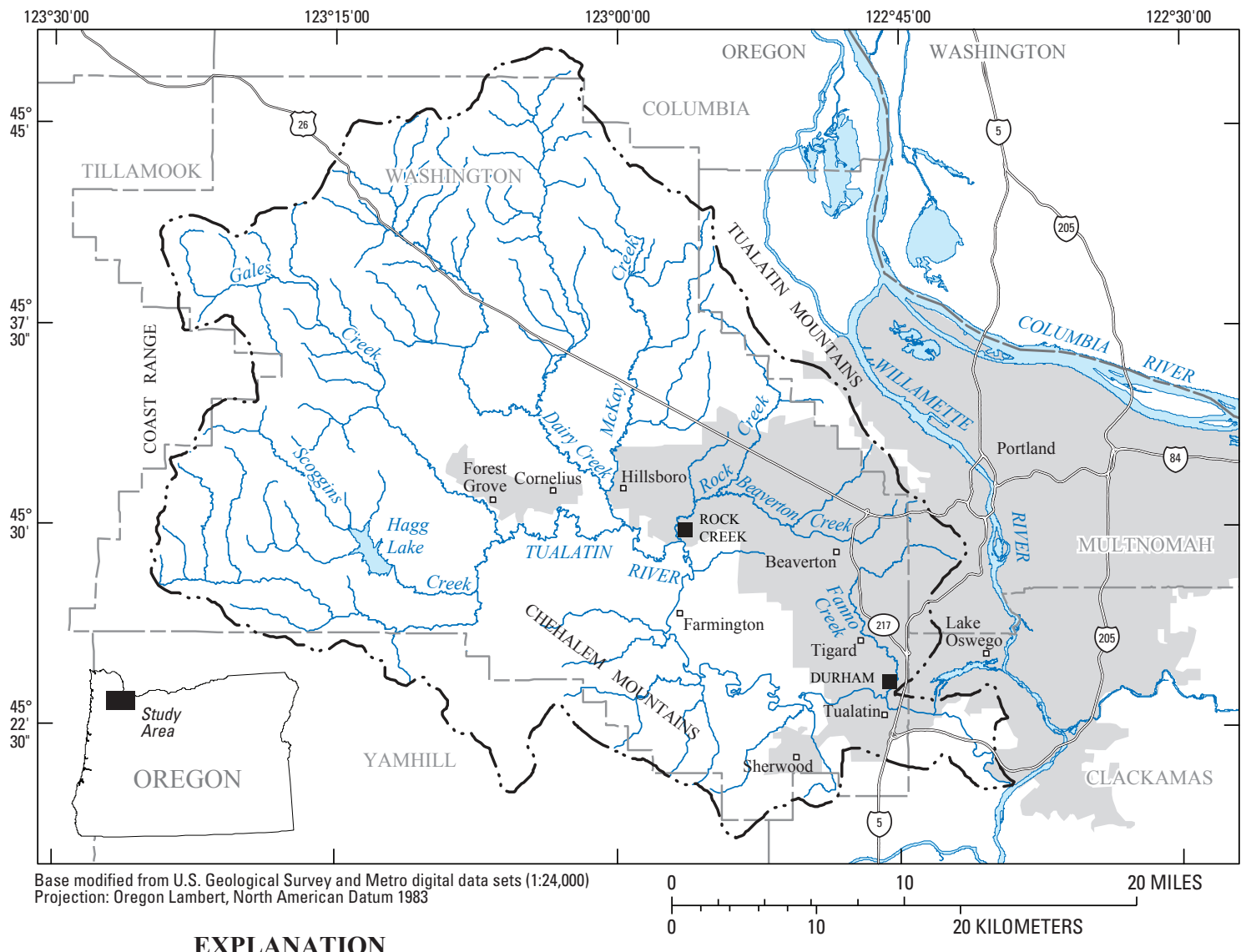

EXPLANATION

Designated urban growth boundary (2001)

-..- Basin boundary

- Wastewater treatment facility

Figure 1. Tualatin River basin, Oregon. 
In a basin that is characterized by cool, wet winters and warm, dry summers, the Tualatin River typically has its highest streamflow of several thousand cubic feet per second in the winter during large eastward-moving Pacific storms, and its lowest flow of less than $200 \mathrm{ft}^{3} / \mathrm{s}$ during late summer. Summer streamflow is reduced by irrigation withdrawals, but augmented by upstream reservoir releases and treated effluent from two large WWTFs. The Rock Creek and Durham WWTFs, operated by Clean Water Services, process an annual average of $60 \mathrm{Mgal} / \mathrm{d}$ of wastewater for more than 480,000 customers. During the low-flow summer period, the WWTFs add about $70 \mathrm{ft}^{3} / \mathrm{s}$ (45 Mgal/d), or as much as 35 percent, to the flow of the Tualatin River (Bonn, 2008a). The Rock Creek and Durham WWTFs are advanced tertiary treatment facilities that use activated sludge treatment and chemical precipitation to remove nutrients and organic matter, followed by chlorination, filtration, and dechlorination for disinfection. The Rock Creek WWTF discharges to the Tualatin River just south of Hillsboro, and the Durham WWTF discharges to the Tualatin River near the mouth of Fanno Creek near Durham (fig. 1).

Tualatin River tributaries are readily grouped by characteristics that mirror the predominant land use within their drainages. Fanno, Rock, and Beaverton Creeks are the major streams draining urban areas of the Tualatin River basin. Fanno Creek has a well-established and completely (100 percent) urbanized drainage. The presence of a large human population, with a relatively dense urban development structure, sanitary and storm-sewer network, and extensive impervious areas, results in a diverse array of potential sources of stream pollution that are different from those in agricultural or forested drainages. In contrast to Fanno Creek, the Gales Creek drainage is predominantly forested (70 percent forest, 27 percent agricultural) and the Dairy Creek drainage has a large percentage of agricultural land use (50 percent) with most of the rest being forested (41 percent; data from 2001 National Land Cover Database, see Homer and others, 2007).

\section{Purpose and Scope}

The occurrence of pharmaceuticals and their metabolites in natural waters can cause adverse effects on ecosystem health. Pharmaceuticals are designed to have physiological effects, and some disrupt the endocrine system or are toxic to aquatic species (Halling-Sørensen and others, 1998; Daughton and Ternes, 1999). Prior to this study, few data existed to quantify the occurrence or concentration of pharmaceutical chemicals in streams of the Tualatin River basin. The primary purpose of this study is to eliminate this data gap as a step toward determining whether this class of compounds affects ecosystem health in the Tualatin River basin. Until a range of contaminant concentrations is measured, the magnitude of the ecological effect cannot be assessed and the appropriate resource management actions cannot be designed.

Of the thousands of pharmaceutical chemicals being manufactured and used, only a small subset was included in this study. The 21 candidate compounds were selected based upon (a) their estimated national use, an important factor in determining which compounds are likely to be detected in stream water, and (b) laboratory recovery performance and compound-specific detection levels achievable in newly developed analytical detection methods. The target analyte list includes a wide range of chemical classes and pharmaceutical uses, from analgesics and antibiotics to anticonvulsants, antihistamines, and stimulants (table 1). The target analytes include several pharmaceutical metabolites; in some cases, the metabolite is likely to be measured in higher concentrations than the parent compound. Though the metabolites are important, the terminology in this report has been simplified such that the 18 pharmaceutical chemicals and 3 metabolites on the target analyte list are commonly grouped together and called "pharmaceuticals."

For many reasons, including the lack of previous data and the high cost of analyzing water samples for pharmaceutical chemicals, this study was by necessity a reconnaissance. The sampling strategy paralleled the objectives of the study, which were to:

- Measure the occurrence and concentration of a target set of pharmaceutical chemicals in streams of the Tualatin River basin, with a focus on highly urbanized drainages;

- Estimate the removal rates of pharmaceutical chemicals within an advanced WWTF; and

- Assess the utility of pharmaceutical chemicals as tracers of human-related contamination of streams.

Most stream samples were collected from six sites in the highly urbanized Fanno Creek subbasin of the Tualatin River basin; two other samples were collected from nearby agricultural and forested drainages for comparison. These sites could be affected by many types of source pathways, but none have treated wastewater sources (other than septic) upstream. Additional samples were collected within, upstream, and downstream of a large advanced WWTF that discharges to the Tualatin River. The emphasis on an urban stream and the 
Table 1. Pharmaceutical chemicals and metabolites included in this study.

[The list of common names is far from complete and is included only for utilitarian purposes. Similarly, the list of uses may be incomplete. This information was obtained from the Merck Index (1989) and from common on-line information sources. CAS, Chemical Abstracts Service. CAS Registry Numbers ${ }^{\circledR}$ is a Registered Trademark of the American Chemical Society. CAS recommends the verification of the CASRNs through CAS Client Services ${ }^{\text {SM }}$.

,- not applicable]

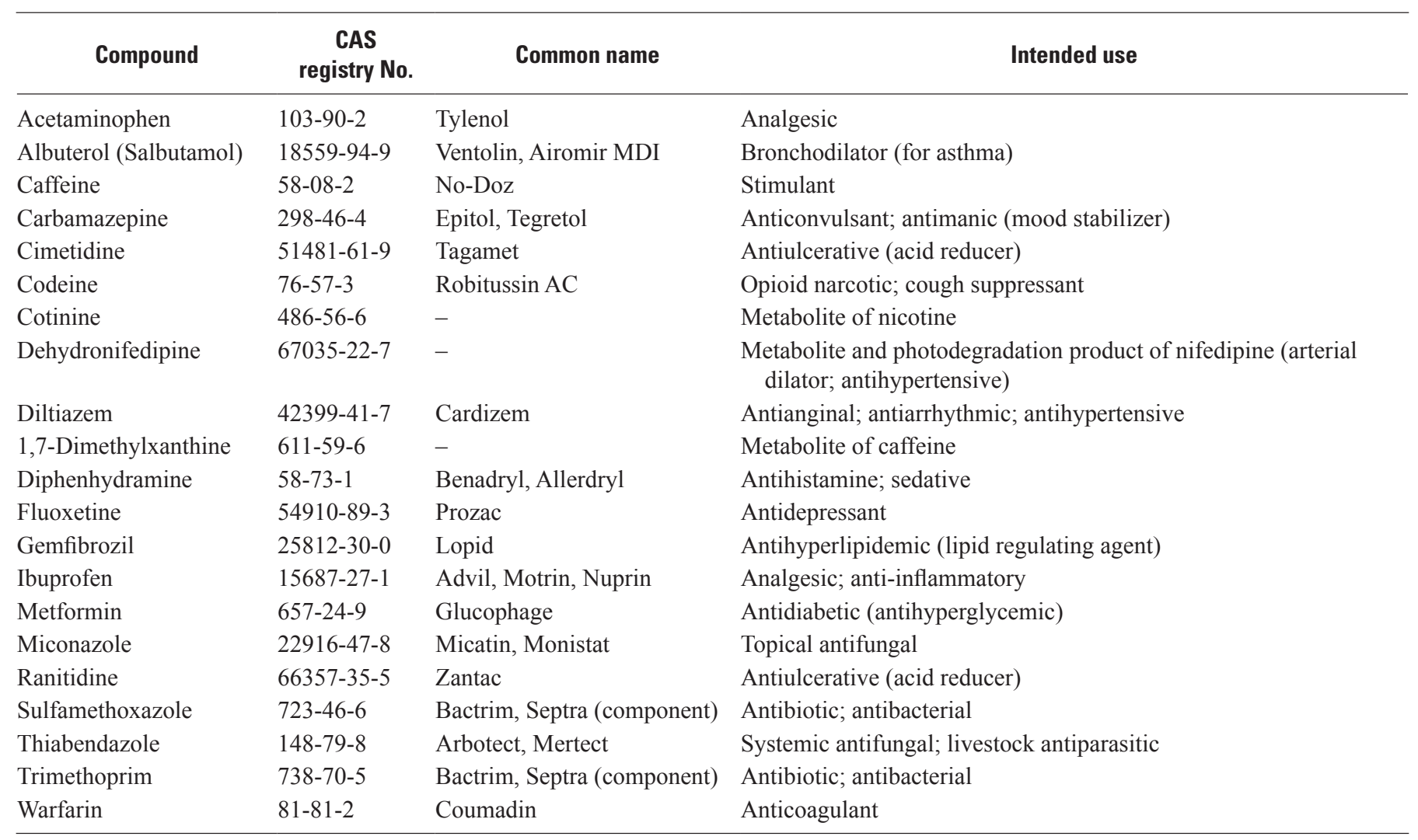

WWTF reflects the information needs of a growing population and those of Clean Water Services, which is the primary stormwater- and wastewater-management utility for the urban areas of Washington County in the Tualatin River basin.

This study was exploratory in nature and limited in its scope. Stream samples were collected just once from each location in late July 2002 during a period of low streamflow preceded by at least 2 weeks of dry weather. Results, therefore, are not indicative of stormwater runoff sources but should capture dry-weather sources such as permitted discharges, leaking sewer lines, illicit dumping, and storm-sewer/sanitarysewer cross-connection problems, if present. The presence or relative importance of stormwater-related sources was not assessed. Sampling during low streamflow is advantageous because the sources are not diluted by rainfall runoff. Similarly, the dry-weather sampling strategy minimized the amount of stormwater delivered to the WWTF and maximized the volumetric fraction of treated effluent in the Tualatin River downstream of the facility's outfall, thus making an assessment of the facility's downstream effects more apparent and straightforward to quantify. These results, however, may not be representative of the presence of pharmaceuticals in the Tualatin River because the sampling design was biased towards sample collection conditions that increased the likelihood of detectable pharmaceutical concentrations.

The purpose of this report is to document the results of this study, draw conclusions related to the study's objectives, and postulate future directions for similar research activities. 


\section{Methodology}

\section{Sample Sites}

Samples for pharmaceutical chemical analysis were collected from eight stream sites (Tualatin River tributaries), two Tualatin River sites upstream and downstream of discharge from an advanced WWTF, and four locations within that treatment facility (table 2, fig. 2). The stream sites were chosen to represent a range of urban, agricultural, and forested land uses in the Tualatin River basin, with an emphasis on the urban areas. Six of the stream sites (sites 1-6) are located in the highly urbanized Fanno Creek drainage, while site 7 on Gales Creek represents more of a forested drainage and site 8 on Dairy Creek has substantial agricultural land use upstream. Sites 1 and 2 in the upper reaches of Fanno Creek, site 5 on Summer Creek, and site 6 on the unnamed creek represent small drainages in largely residential urban areas. The Summer Creek drainage may have a larger fraction of residences with on-site septic systems rather than service from the sanitary sewer system. The remaining two sites farther downstream on Fanno Creek (sites 3 and 4) include increasing amounts of commercial and industrial land use. In addition to pointsource discharges, few of which are present in the Fanno Creek drainage, pharmaceutical chemicals may be present in urban streams as a result of accidental discharge, intentional dumping of waste (from a recreational vehicle, for example), sanitary-sewer/storm-sewer cross connections, leaking sewer lines, and failing septic systems, to name a few. Caffeine may be present in streams as a result of people discarding coffeecup residue on the street, which then can be washed to a storm drain and from there into the nearest creek.

Samples were collected from four locations within Clean Water Service's Durham WWTF to assess the concentrations of pharmaceuticals that are delivered to the facility and their removal from the waste stream. The Durham WWTF is an advanced treatment facility that uses state-of-the-art treatment technology and attains a higher level of phosphorus removal, for example, than 98 percent of WWTFs in the United States (Clean Water Services, 2002). The facility uses screening, primary settling, enhanced biological treatment, tertiary chemical treatment, chlorination, sand-bed filtration, aeration, and dechlorination processes (fig. 3). Although the treatment is designed primarily to remove solids, oxygen demand, ammonia, and phosphorus, the effluent is near drinking-water

Table 2. Samples collected for pharmaceutical chemical analysis in the Tualatin River basin, Oregon, 2002.

[Sampling site No.: Location of sampling sites are shown in figure 2. WWTF, wastewater treatment facility; -, not applicable]

\begin{tabular}{|c|c|c|c|c|c|c|c|}
\hline $\begin{array}{l}\text { Sampling } \\
\text { site No. }\end{array}$ & Site type & Site name & $\begin{array}{c}\text { Site } \\
\text { identification } \\
\text { No. }\end{array}$ & $\begin{array}{c}\text { Drainage } \\
\text { area } \\
\left(\mathrm{mi}^{2}\right)\end{array}$ & $\begin{array}{c}\text { Sample } \\
\text { type }\end{array}$ & Date & Time \\
\hline \multirow[t]{2}{*}{1} & Urban & Fanno Creek at 56th Avenue & 14206900 & 2.4 & regular & $7-30-2002$ & 9:00 \\
\hline & & & & & duplicate & $7-30-2002$ & $9: 00$ \\
\hline \multirow[t]{2}{*}{2} & Urban & Fanno Creek near Allen Boulevard & 14206925 & 8.9 & regular & $7-30-2002$ & $9: 40$ \\
\hline & & & & & duplicate & $7-30-2002$ & $9: 40$ \\
\hline 3 & Urban & Fanno Creek at Highway 99W & 14206942 & 24.8 & regular & $7-30-2002$ & $9: 15$ \\
\hline \multirow[t]{2}{*}{4} & Urban & Fanno Creek at Durham City Park & 452348122454701 & 31.7 & regular & $7-30-2002$ & $10: 10$ \\
\hline & & & & & duplicate & $7-30-2002$ & $10: 20$ \\
\hline \multirow[t]{2}{*}{5} & Urban & Summer Creek at Fowler Middle School & 452559122472401 & 6.2 & regular & $7-29-2002$ & $9: 40$ \\
\hline & & & & & duplicate & $7-29-2002$ & $9: 40$ \\
\hline 6 & Urban & Unnamed Creek at Walnut Street in Tigard & 452547122465900 & 0.8 & regular & $7-29-2002$ & $10: 10$ \\
\hline 7 & Forested & Gales Creek at Old Highway 47 & 14204530 & 74.7 & regular & $7-25-2002$ & $10: 20$ \\
\hline 8 & Agricultural & Dairy Creek at Highway 8 & 14206200 & 229 & regular & $7-25-2002$ & $11: 25$ \\
\hline 9 & Integrator & Tualatin River at Cook Park & 14206800 & 655 & regular & $7-31-2002$ & 10:00 \\
\hline 10 & Integrator & Tualatin River at Boones Ferry Road & 14206960 & 692 & regular & $7-31-2002$ & 11:00 \\
\hline \multirow[t]{5}{*}{11} & WWTF & Durham WWTF - headworks & 452359122454501 & - & regular & $7-31-2002$ & 11:00 \\
\hline & & Durham WWTF - pre-filtration & 452359122454502 & - & regular & $7-31-2002$ & $13: 35$ \\
\hline & & Durham WWTF - post-filtration & 452359122454503 & - & regular & $7-31-2002$ & $10: 20$ \\
\hline & & Durham WWTF - effluent & 452359122454504 & - & regular & $7-31-2002$ & $10: 30$ \\
\hline & & & & & duplicate & $7-31-2002$ & $10: 40$ \\
\hline- & Quality assurance & Blank (organic blank water) & - & - & blank & $7-31-2002$ & 16:00 \\
\hline
\end{tabular}




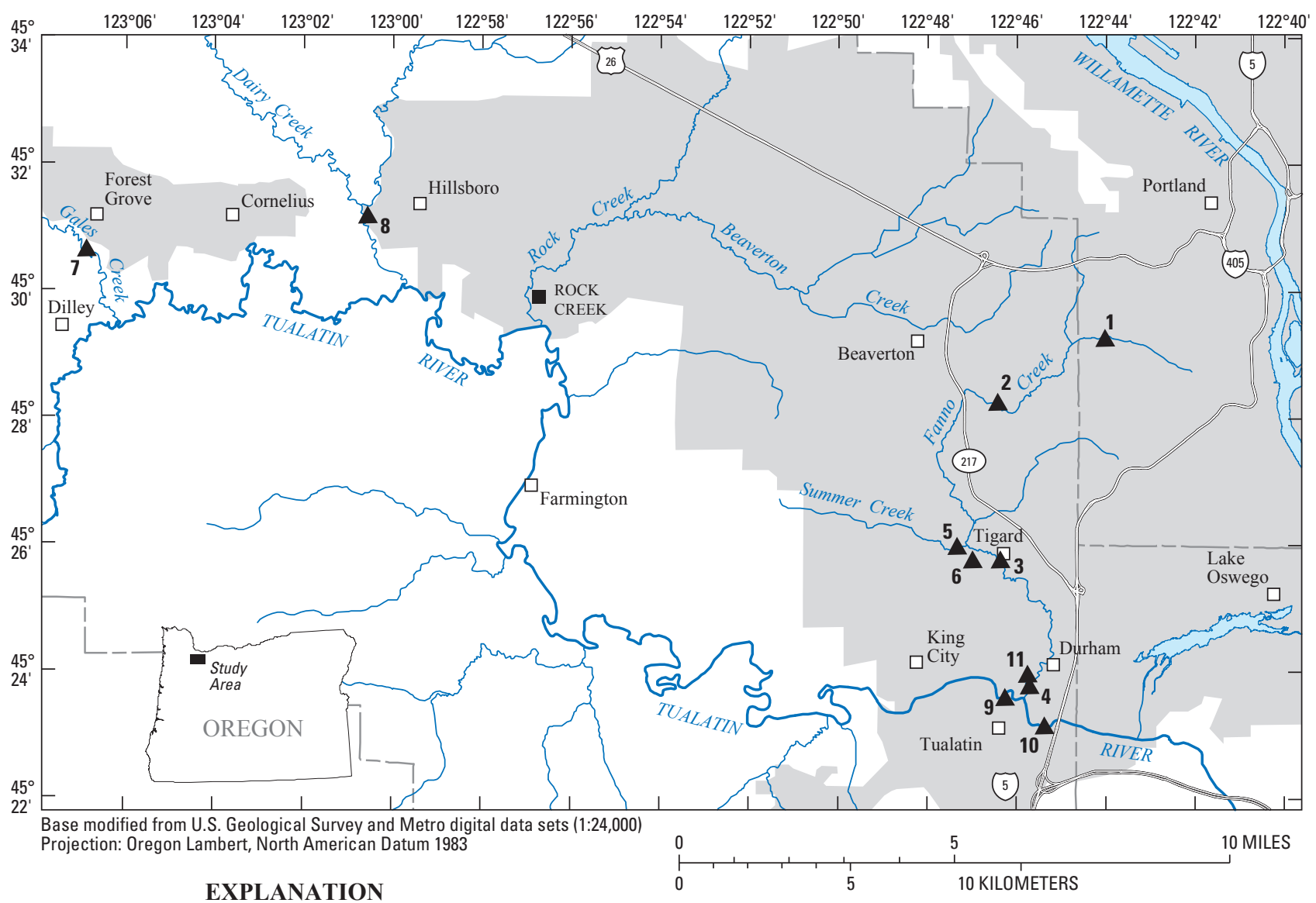

Designated urban growth boundary (2001)

A Sampling site and No.

1 Fanno Creek at 56th Avenue

2 Fanno Creek near Allen Boulevard

3 Fanno Creek at Highway 99W

4 Fanno Creek at Durham City Park

5 Summer Creek at Fowler Middle School

6 Unnamed Creek at Walnut Street in Tigard

7 Gales Creek at Old Highway 47

8 Dairy Creek at Highway 8

9 Tualatin River at Cook Park

10 Tualatin River at Boones Ferry Road

11 Durham wastewater treatment facility

- Rock Creek wastewater treatment facility

Figure 2. Location of sites sampled in this study.

quality and typically dilutes many of the regulated chemicals in the Tualatin River's receiving water. The Durham WWTF serves a customer base of more than 200,000 people and has a dry-weather discharge of about $25 \mathrm{ft}^{3} / \mathrm{s}(16 \mathrm{Mgal} / \mathrm{d})$. On July 31,2002 , the day of sample collection, the mean facility discharge was $24 \mathrm{ft}^{3} / \mathrm{s}$, but ranged as high as $40 \mathrm{ft}^{3} / \mathrm{s}$ and as low as about $12 \mathrm{ft}^{3} / \mathrm{s}$. Samples of influent (at the headworks) and effluent were collected. Additional samples were collected before and after the filtration step, which is downstream of primary, secondary, and tertiary treatment and after chlorination, but prior to final aeration and dechlorination (fig. 3). Samples were collected without attempting to follow a single parcel of influent through the WWTF; the 6-hour residence time and multiple recirculation pathways within the facility make such a sampling strategy difficult to perform. Results from these samples, therefore, are only strictly comparable if the influent waste stream was somewhat invariant in its loading of pharmaceutical chemicals. 


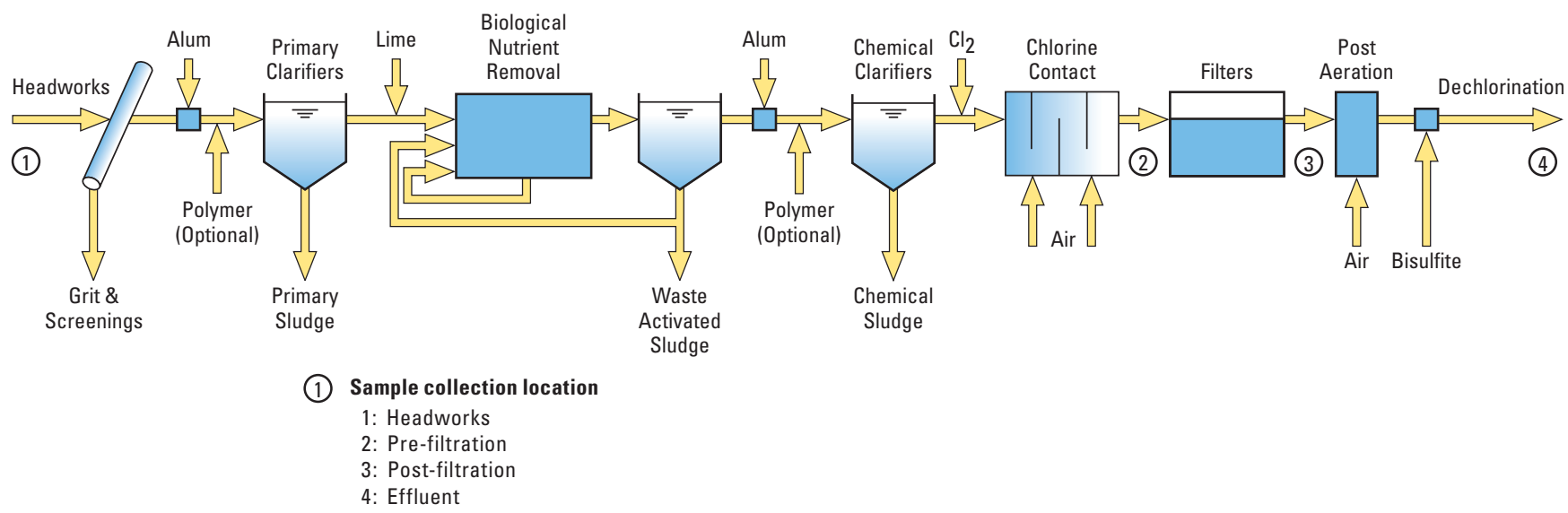

Figure 3. Summertime treatment processes at Clean Water Services' Durham wastewater treatment facility in 2002. Water samples were collected at the four marked locations. (Diagram reproduced with permission from Clean Water Services.)

To assess the instream effect of WWTF effluent, samples were collected from the Tualatin River 0.6 mi upstream (site 9, Cook Park) and 0.6 mi downstream (site 10, Boones Ferry Road) of the Durham WWTF outfall on the same day and at about the same time that samples were collected from the WWTF. On July 31, 2002, streamflow in the Tualatin River was about $171 \mathrm{ft}^{3} / \mathrm{s}$ upstream of the outfall and $198 \mathrm{ft}^{3} / \mathrm{s}$ downstream of the outfall. These streamflows were estimated based on measured streamflows at several streamflow-gaging stations upstream and downstream of the WWTF outfall.

\section{Sampling and Processing Methods}

Water samples from stream and river sites were collected using standard USGS protocols. Where stream size and depth allowed, the depth- and width-integrating equal-width increment (EWI) water-sampling technique was used. In the EWI method, a sample is collected by lowering and raising a sampler through the water column at a constant specified rate, repeating the process at the center of a set of equally spaced locations in the stream cross-section, and compositing the collected waters (Edwards and Glysson, 1999). EWI samples were collected using either a DH-81 hand-held sampler for wadeable streams or a D-77 sampler for non-wadeable streams with a 3-L Teflon ${ }^{\circledR}$ sample bottle and a Teflon ${ }^{\circledR}$ cap/ nozzle assembly. The unnamed creek at Walnut Street (site 6, fig. 2) was not deep or large enough to use the EWI method; instead, a grab sample was collected using the protocols and considerations for nonstandard sampling documented by Shelton (1994). Samples were placed on ice for transport back to the USGS Oregon Water Science Center laboratory for later filtration.

Samples of water were collected from four different locations at the Durham WWTF. Because of safety, access, and structural considerations at the facility, nonstandard sampling techniques were used, typically resulting in grab samples of the source water. Samples were placed on ice before transporting them to the laboratory for later filtration.
Special protocols were followed to prevent contamination of the water samples. The sampling crew was careful to avoid contact with or consumption of any products or materials that contain the target analytes in this study. For example, the potential introduction of trace amounts of caffeine into collected samples was minimized through the crew's abstention from caffeine-containing beverages (such as coffee), and protecting the samples from contact with human exhalations. These types of sample-handling and contamination-avoidance procedures are described by Lewis and Zaugg (2003) in the USGS National Field Manual.

Standard USGS procedures for handling and filtering samples containing organic compounds were followed prior to the shipment of samples to the USGS National Water Quality Laboratory (NWQL) in Denver, Colorado. Samples were filtered using a stainless steel or aluminum 142-mm or 293-mm diameter plate-filter assembly with a 0.7 -micron pore size glass-fiber filter. A valveless-piston variable-speed pump with Teflon ${ }^{\circledR}$ tubing was used, and sufficient filtrate from each sample was collected to fill two 1-L amber glass bottles that had been cleaned and baked at $350^{\circ} \mathrm{C}$. Standard protocols for sample processing are documented in section 5.2.2 of the USGS National Field Manual (Wilde and others, 2004). All filtered samples were shipped on ice to the USGS NWQL for analysis.

The use of filtered water samples in this study, a requirement of the laboratory analysis method, means that the results reflect only the dissolved fraction of the target compounds' total mass in the collected water samples. Although many of the target compounds are fairly water soluble (some even are ionized under neutral $\mathrm{pH}$ conditions, which makes them extremely water soluble), a fraction of their mass in a whole-water sample may be associated with suspended particulate material. As a result, the measured concentrations from a filtered sample may be lower than the concentration that would be measured in a whole-water sample. 


\section{Laboratory Analysis}

Filtered water samples were analyzed for a suite of 18 pharmaceuticals and 3 metabolites by the Methods Research and Development group at the USGS NWQL using a relatively new analytical method (Cahill and others, 2004; Furlong and others, 2008). In that method, the target analytes and an added performance surrogate first were removed from filtered 1-L water samples by passing the water through a solid-phase extraction (SPE) cartridge. The analytes then were eluted from the SPE cartridge using small volumes of methanol and acidified methanol, concentrated to near dryness, reconstituted into formate buffer with an internal standard, and filtered. The concentrates were analyzed using highperformance liquid chromatography interfaced with a mass spectrometer using electrospray ionization operated in the positive-ion mode (HPLC-ESI-MS). Selected-ion monitoring MS was used to improve sensitivity and specificity. For more details on the specific materials, extraction procedures, and instrument conditions, see Cahill and others (2004) or Furlong and others (2008).

The analytical method used in this study was still under development at the time of sample collection and analysis. For that reason, the lists of target analytes in the published method papers (Cahill and others, 2004; Furlong and others, 2008) are slightly different from the target analytes in this study. In the most recent version of the analytical method documented by Furlong and others (2008), 11 pharmaceuticals and 3 metabolites were analyzed, all of which were included in this study. Seven additional compounds (cimetidine, fluoxetine, gemfibrozil, ibuprofen, metformin, miconazole, and ranitidine) were included in this study, six of which also were included by Cahill and others (2004). Of the 21 compounds analyzed in this study, only miconazole was omitted by both of the published method papers. Method detection limits and spike recovery information for all of the target analytes are included later in this report with the results and the quality assurance data. Because this method incorporates a mass spectrometer as a detector, the qualitative identification of a compound can be verified, if not reliably quantified, at concentrations less than the method detection limit (Childress and others, 1999; Bonn, 2008b); such detections are reported as estimated concentrations only.

\section{Quality Assurance}

The quality assurance program for this study included field duplicate samples and equipment blanks, and laboratory blanks and spikes. The field equipment blank was composed of certified organic blank water (EM Science, Universal Blank Water, lot \#42044: purity verification data available upon request) that was filtered and handled using the same procedures as those used for the stream samples. Duplicate water samples were collected at five sites (table 2) to test the reproducibility of field and laboratory procedures. In addition, as part of the laboratory method, each set of analyzed samples included a laboratory blank sample and a spiked blank sample.

Spike recovery results from this study, and from 67 additional laboratory spike samples analyzed during method development in 2002, demonstrated that the analytical method produced mixed results for this set of 21 target analytes (table 3 ). For 11 of the analytes, the spike recovery was consistently greater than 60 percent, and results were deemed reliable enough to report without qualification. Mean spike recoveries for eight other analytes were between 20 and 60 percent; this less reliable recovery requires that quantified concentrations for these compounds be reported only as estimates. Spike recoveries for the final two compounds on the target analyte list, metformin and miconazole, were poor (6 percent or less); any detections of these compounds were reported without quantification.

Blank samples from the field and the laboratory were, with one exception, devoid of the target analytes. A low-level concentration of fluoxetine $(0.0039 \mu \mathrm{g} / \mathrm{L})$ was detected in the equipment blank sample, reducing the reliability of any lowlevel detections for that compound; fluoxetine results already were qualified as estimates based on low spike recovery results. No other target compounds were detected in the blank samples. Table 3 lists the spike recovery data, blank results, and interpreted reporting guidance for each compound (report without qualification, report as estimate, etc.).

Duplicate sample results showed good agreement, providing assurance that the detection frequency and the quantified concentrations were reliable. For the five duplicate water samples included in this study, a target analyte was detected in 15 instances in which a paired duplicate result also was available. In 12 of the 15 instances, the analyte was detected in both samples; in only 3 instances was a compound detected in only 1 of the paired samples. As might be expected, the percent relative difference in the quantified concentrations of paired results was higher for the lowest concentrations. For concentrations less than $0.1 \mu \mathrm{g} / \mathrm{L}$, the relative percent difference was about 19 percent $(10$ comparisons), and that value decreased to about 5 percent for concentrations greater than $0.1 \mu \mathrm{g} / \mathrm{L}$ ( 2 comparisons). Concentrations closer to the detection limit, therefore, are expected to be more uncertain than those that are well above the detection limit.

Matrix interferences can cause quality assurance issues that are difficult to quantify. The influent sample from the Durham WWTF, although filtered, had a complex organic chemical signal that could not completely be cleaned up or avoided during the sample extraction and concentration process. These interfering chemicals were incompletely separated from the target analytes during the chromatographic procedure, thus decreasing signal-to-noise ratios, increasing detection limits, and decreasing the certainty of compound identification and quantitation. Although results from the Durham influent sample were double-checked by re-running the analysis, all those results have a greater uncertainty due to matrix interferences. 
Table 3. Results of quality control analyses for pharmaceutical chemicals included in this study.

[The 2002 spike recovery data were from laboratory data collected throughout fiscal year 2002 — before, during, and after this study. \%, percent; Std. Dev., standard deviation of spike recovery results; $\mu \mathrm{g} / \mathrm{L}$, microgram per liter]

\begin{tabular}{|c|c|c|c|c|}
\hline Compound & $\begin{array}{l}\text { Clean } \\
\text { blanks? }\end{array}$ & $\begin{array}{c}\text { Range of } \\
\text { spike recovery } \\
\text { (this study, \%) }\end{array}$ & $\begin{array}{c}\text { Mean (and Std. Dev.) } \\
\text { of } 67 \text { set spikes } \\
\text { (2002 results, \%) }\end{array}$ & Comment \\
\hline Albuterol (Salbutamol) & yes & $70-90$ & $74(10)$ & Results reported without qualification. \\
\hline Caffeine & yes & $75-104$ & $85(16)$ & Results reported without qualification. \\
\hline Codeine & yes & $66-91$ & $94(25)$ & Results reported without qualification. \\
\hline Cotinine & yes & $68-92$ & $74(12)$ & Results reported without qualification. \\
\hline Dehydronifedipine & yes & $71-100$ & $77(15)$ & Results reported without qualification. \\
\hline Diltiazem & yes & $48-61$ & $47(11)$ & Reported concentrations are estimates. \\
\hline Gemfibrozil & yes & $59-87$ & $30(21)$ & Reported concentrations are estimates. \\
\hline Ibuprofen & yes & $24-121$ & $51(24)$ & $\begin{array}{l}\text { Variable spike recovery. Imprecise quantitation. Reported } \\
\text { concentrations are estimates. }\end{array}$ \\
\hline Metformin & yes & $0-2$ & $4(4.8)$ & $\begin{array}{l}\text { Very low probability of low-level detection. No concentrations } \\
\text { reported, only detections. }\end{array}$ \\
\hline Miconazole & yes & $1-22$ & $6(7.1)$ & $\begin{array}{l}\text { Very low probability of low-level detection. No concentrations } \\
\text { reported, only detections. }\end{array}$ \\
\hline Ranitidine & yes & $45-56$ & $41(13)$ & Reported concentrations are estimates. \\
\hline Sulfamethoxazole & yes & $64-90$ & $51(18)$ & Reported concentrations are estimates. \\
\hline Thiabendazole & yes & $73-94$ & $75(16)$ & Results reported without qualification. \\
\hline
\end{tabular}

\section{Pharmaceutical Chemical Detections and Concentrations}

\section{Reconnaissance Results}

This reconnaissance of pharmaceutical chemicals in streams of the Tualatin River basin was conducted in late July 2002. Stream samples were collected between July 25 and July 30, and the Tualatin River and the Durham WWTF were sampled on July 31 (table 2). Late July in western Oregon typically is warm and dry, and streams in the Tualatin River basin at that time are composed predominantly of groundwater baseflow. In the case of the Tualatin River, additional flow comes from upstream reservoir releases and the treated

effluent from two advanced WWTFs. Prior to sample collection, no measurable rain had occurred since July 8 , although a trace was recorded on July 26 (USGS data: see site 452359122454500, for example, at http://or.water.usgs.gov/ grapher/).

A wide variety of sources can deliver pharmaceutical chemicals to streams. During dry weather, such sources might include failing septic or other on-site waste-treatment systems, leaking sewer lines, permitted and accidental discharges, illicit and unpermitted dumping, sanitary-sewer/storm-sewer cross connections, and unmanaged or poorly managed pet and livestock wastes. Stormwater sources are not included in this reconnaissance, which is important to remember because the storm-sewer system in the study area generally discharges to the stream network rather than to a treatment facility. The dry-weather sampling increased the chances of detecting 
pharmaceuticals from dry-weather sources because dilution by rainfall was avoided. The absence of rain also meant that the Durham WWTF was handling its normal load of domestic and other municipal/industrial sewage; therefore, the effect of WWTF effluent on the Tualatin River was representative of summer low-flow conditions and the relative proportion of treated effluent in the river was somewhat maximized, thus making its source load easier to detect.

Of the 21 target analytes included in this study, six were not detected in any sample, and only six were detected in any of the stream or river samples (tables 4 and $\underline{5}$ ). Stream sample detections included cotinine, caffeine, acetaminophen, carbamazepine, codeine, and sulfamethoxazole, in decreasing order of detection frequency. Sulfamethoxazole and carbamazepine primarily were found in the Tualatin River rather than in the smaller drainages, and the main source of the two compounds in the river probably was treated WWTF effluent; none of the smaller creek sites have WWTF discharges upstream of their sampling locations. Fifteen of the 21 target analytes were detected in WWTF influent; in contrast, only five were detected in treated effluent.

The most commonly detected compound was cotinine, which was found in every urban stream sample, both samples from the Tualatin River, and all WWTF samples. Cotinine is a metabolite of nicotine, which is an ingredient of tobaccocontaining products; therefore, cotinine is delivered to municipal WWTFs on a consistent basis through the sanitary sewer. Given the widespread outdoor use of nicotinecontaining products, it is not surprising that cotinine was detected in all urban stream samples. Similarly, caffeine was the second most-detected compound, and it also was found in all urban stream samples. Caffeine is present in high concentrations in coffee-based beverages, soft drinks, and energy drinks, and the propensity of many people to discard the remains of those beverages on streets and parking lots may account for the prevalence of caffeine in urban stream samples. Wash-off from streets and parking lots typically is conveyed to the nearest stream through the storm-sewer system with minimal opportunity for degradation, and little of the storm-sewer network has been retrofitted to deliver stormwater to wetlands or other naturalized treatment facilities. Note that if wash-off from streets and parking lots was instrumental in delivering these compounds to streams, then the dry-weather sampling performed in this study may have been affected by previous stormwater delivery processes. Despite the universal detection of caffeine in urban stream samples in this study, none of those samples included detections of 1,7-dimethylxanthine, which is the primary metabolite of caffeine (Guerreiro and others, 2008) and is present in high concentrations in untreated wastewater. The absence of this metabolite in urban stream samples reinforces the suggestion that the source of caffeine to these urban streams does not include processing through the human body, and therefore does not come from treatment, septic, or sewerrelated sources.

Most of the target analytes in this study (15 of 21) were not detected in stream or river samples. Only three compounds (acetaminophen, caffeine, cotinine) were detected in urban stream samples, and the great majority of those detections were at concentrations less than $0.04 \mu \mathrm{g} / \mathrm{L}$ with half of those detections at less than $0.01 \mu \mathrm{g} / \mathrm{L}$ (table 4). For perspective, $0.01 \mu \mathrm{g} / \mathrm{L}$ is nearly identical to half a drop of the pure compound diluted into a 660,000-gal Olympic-sized swimming pool, and 660,000 gal is the total amount of water used if you were to flush a modern 1.6-gal water-saving toilet 25 times a day for the next 45 years. With only a couple of exceptions, the detected concentrations were less than about 4 to 5 times the analytical method detection limit. One sample did show a substantially higher concentration of caffeine $(0.314 \mu \mathrm{g} / \mathrm{L})$ than any other stream sample, perhaps indicating a nearby source. Only two compounds (acetaminophen, carbamazepine) were detected in Gales Creek and only one (caffeine) was detected in Dairy Creek, and all three were estimated at concentrations less than their method detection limits. Even the Tualatin River samples, which were affected by one or more upstream WWTF sources, showed only four compound detections (carbamazepine, codeine, cotinine, sulfamethoxazole), and two (codeine and sulfamethoxazole) of the four were estimated at concentrations less than the method detection limit. In general, this reconnaissance of the target pharmaceutical chemicals indicates that these compounds either are not present in Tualatin River basin streams or are present only at trace concentrations that are many orders of magnitude below their usage or pharmacological dosing levels. For many of these compounds, it is not yet known whether these trace concentrations have ecological effects.

The effects of upstream land use were not clearly defined with the limited number of samples collected in this study. The samples collected from the Gales (forested) and Dairy (agricultural) Creek sites, however, certainly had fewer of the target compounds detected and all such detections were estimated at concentrations less than their method detection limits. The target analyte list, however, did not include the most commonly used antibiotics used in veterinary medicine, which might partially explain the paucity of detections in the agricultural drainage. The biggest difference between these two samples and the urban stream samples was the consistent presence of caffeine and cotinine in the urban samples. Caffeine and cotinine, therefore, may be good indicators for sources associated with urban areas. The Gales and Dairy Creek sites have little upstream urban land use (2 and 7 percent, respectively). 


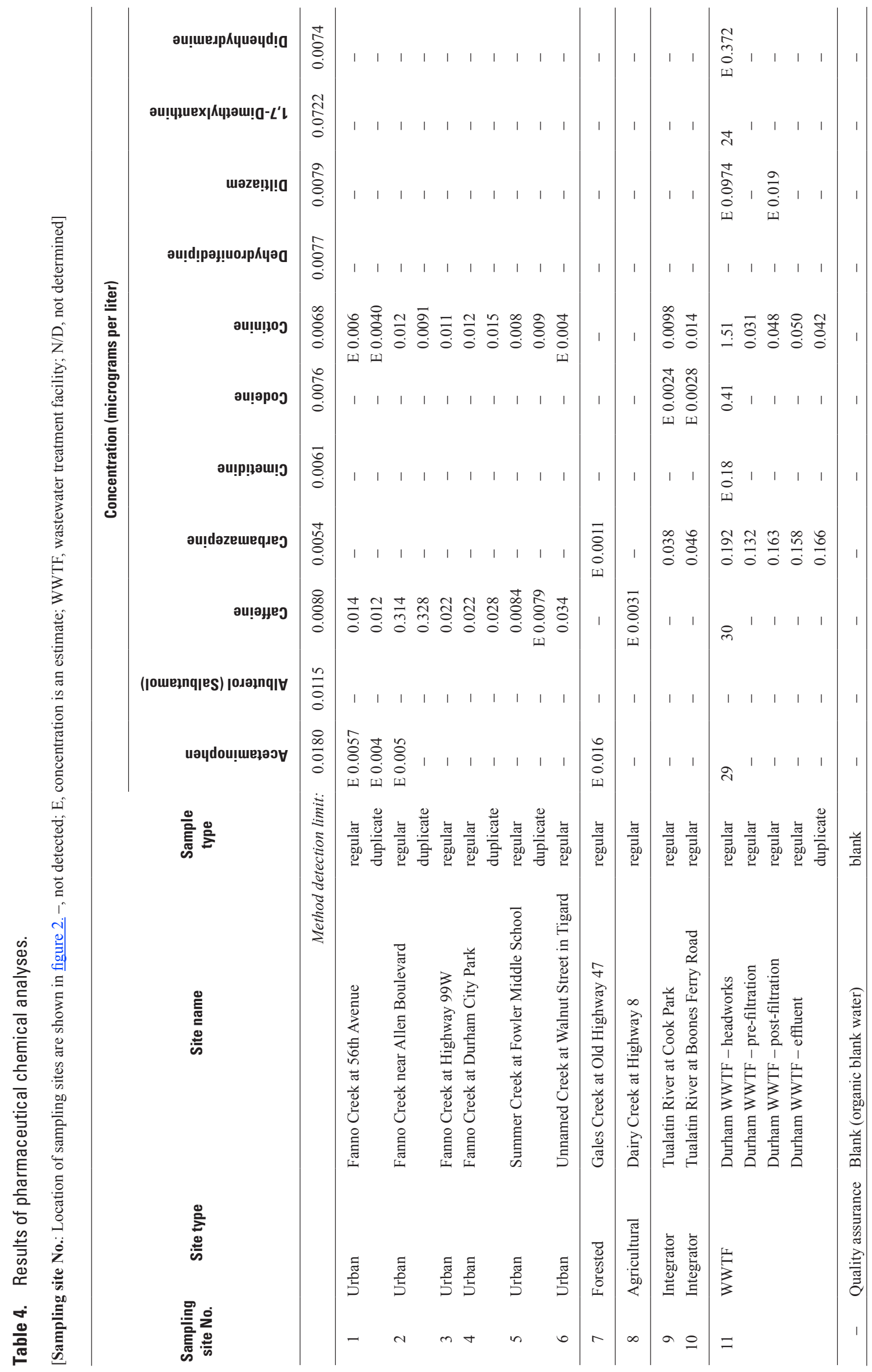




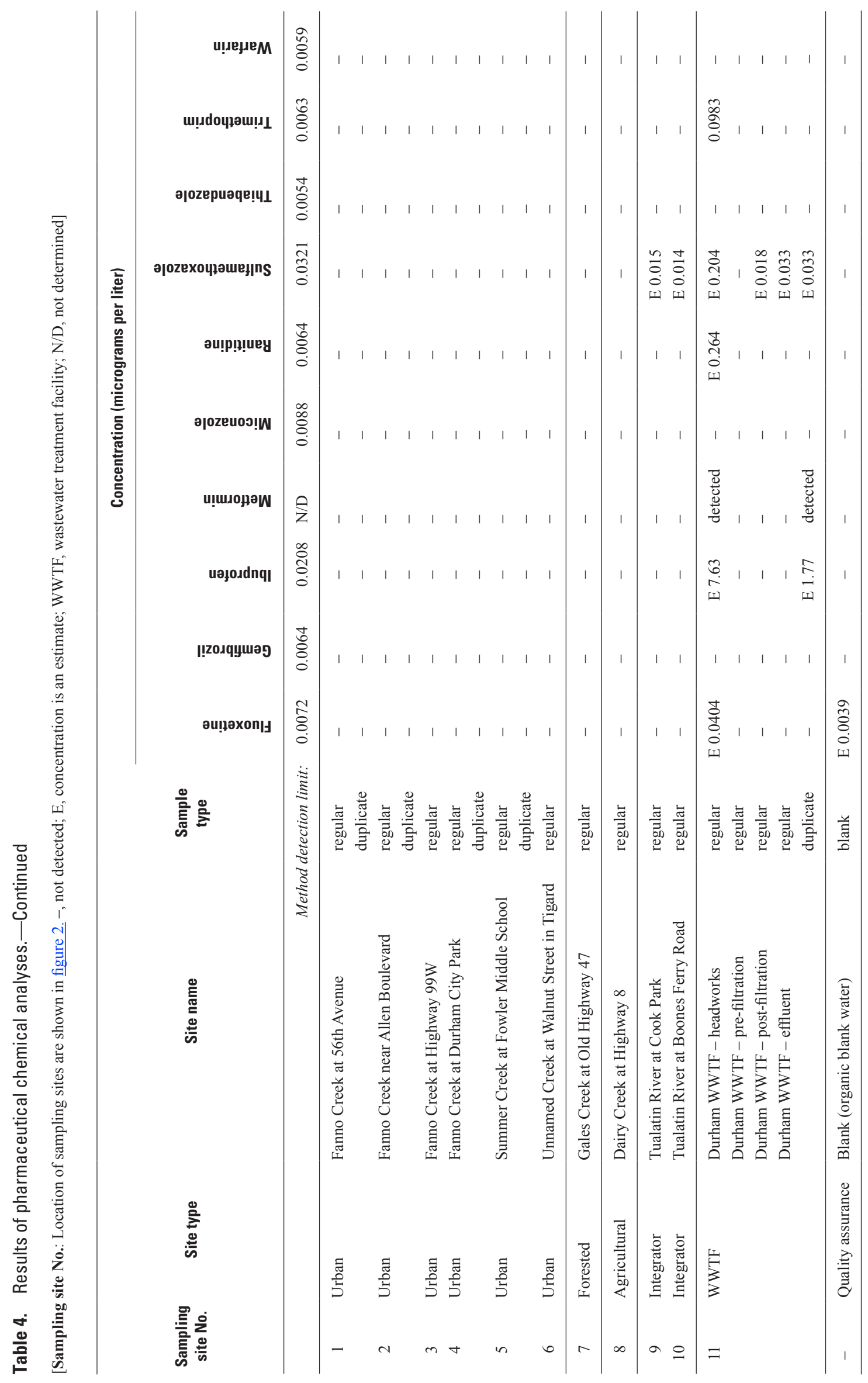


Table 5. Detection frequency for pharmaceutical chemicals analyzed in this study.

[Grey shading highlights combinations with no detections. WWTF, wastewater treatment facility]

\begin{tabular}{|c|c|c|c|c|c|c|}
\hline \multirow{2}{*}{ Compound } & \multicolumn{6}{|c|}{ Detection frequency (detections/number of samples) } \\
\hline & All streams & Urban streams & Forested streams & Agricultural streams & Tualatin River & WWTF \\
\hline Acetaminophen & $3 / 10$ & $2 / 6$ & $1 / 1$ & $0 / 1$ & $0 / 2$ & $1 / 4$ \\
\hline Albuterol (Salbutamol) & $0 / 10$ & $0 / 6$ & $0 / 1$ & $0 / 1$ & $0 / 2$ & $0 / 4$ \\
\hline Caffeine & $7 / 10$ & $6 / 6$ & $0 / 1$ & $1 / 1$ & $0 / 2$ & $1 / 4$ \\
\hline Carbamazepine & $3 / 10$ & $0 / 6$ & $1 / 1$ & $0 / 1$ & $2 / 2$ & $4 / 4$ \\
\hline Cimetidine & $0 / 10$ & $0 / 6$ & $0 / 1$ & $0 / 1$ & $0 / 2$ & $1 / 4$ \\
\hline Codeine & $2 / 10$ & $0 / 6$ & $0 / 1$ & $0 / 1$ & $2 / 2$ & $1 / 4$ \\
\hline Cotinine & $8 / 10$ & $6 / 6$ & $0 / 1$ & $0 / 1$ & $2 / 2$ & $4 / 4$ \\
\hline Dehydronifedipine & $0 / 10$ & $0 / 6$ & $0 / 1$ & $0 / 1$ & $0 / 2$ & $0 / 4$ \\
\hline Diltiazem & $0 / 10$ & $0 / 6$ & $0 / 1$ & $0 / 1$ & $0 / 2$ & $2 / 4$ \\
\hline 1,7-Dimethylxanthine & $0 / 10$ & $0 / 6$ & $0 / 1$ & $0 / 1$ & $0 / 2$ & $1 / 4$ \\
\hline Diphenhydramine & $0 / 10$ & $0 / 6$ & $0 / 1$ & $0 / 1$ & $0 / 2$ & $1 / 4$ \\
\hline Fluoxetine & $0 / 10$ & $0 / 6$ & $0 / 1$ & $0 / 1$ & $0 / 2$ & $1 / 4$ \\
\hline Gemfibrozil & $0 / 10$ & $0 / 6$ & $0 / 1$ & $0 / 1$ & $0 / 2$ & $0 / 4$ \\
\hline Ibuprofen & $0 / 10$ & $0 / 6$ & $0 / 1$ & $0 / 1$ & $0 / 2$ & $2 / 4$ \\
\hline Metformin & $0 / 10$ & $0 / 6$ & $0 / 1$ & $0 / 1$ & $0 / 2$ & $2 / 4$ \\
\hline Miconazole & $0 / 10$ & $0 / 6$ & $0 / 1$ & $0 / 1$ & $0 / 2$ & $0 / 4$ \\
\hline Ranitidine & $0 / 10$ & $0 / 6$ & $0 / 1$ & $0 / 1$ & $0 / 2$ & $1 / 4$ \\
\hline Sulfamethoxazole & $2 / 10$ & $0 / 6$ & $0 / 1$ & $0 / 1$ & $2 / 2$ & $3 / 4$ \\
\hline Thiabendazole & $0 / 10$ & $0 / 6$ & $0 / 1$ & $0 / 1$ & $0 / 2$ & $0 / 4$ \\
\hline Trimethoprim & $0 / 10$ & $0 / 6$ & $0 / 1$ & $0 / 1$ & $0 / 2$ & $1 / 4$ \\
\hline Warfarin & $0 / 10$ & $0 / 6$ & $0 / 1$ & $0 / 1$ & $0 / 2$ & $0 / 4$ \\
\hline
\end{tabular}

\section{Comparison to Other Data}

Samples were collected by the USGS in 1999-2000 from 139 streams across the United States, including several from Oregon streams (Barnes and others, 2002; Kolpin and others, 2002), in a reconnaissance of pharmaceutical chemicals, hormones, and organic wastewater contaminants. Results from that investigation provide a useful comparison to this study. The list of pharmaceutical compounds included in the national reconnaissance was similar to the target analyte list in this study, largely because the same analytical method was used. Seventeen of the target compounds in this study were included in the national reconnaissance, and of the six compounds that were detected in stream samples in this study, only carbamazepine was not included in the national reconnaissance. Results for the five remaining detected compounds are compared to results from the national study in figure 4. The concentrations detected in this study are similar to and consistent with those from the national study. Maximum concentrations detected in this study, however, were at least an order of magnitude less than the maxima from the national study. This could be due to chance, given that the national study included about 10 times more samples, but it also may indicate that samples from the Tualatin River basin have fewer or weaker upstream sources of the target pharmaceuticals.

In both the national reconnaissance and this study, a sample was collected from the Tualatin River at Boones Ferry Road (site 10). The sample in the national study was collected on June 3,2000, was preceded by only 3 days of dry weather, and showed detections for caffeine, codeine, 1,7-dimethylxanthine, sulfamethoxazole, and trimethoprim. In this study, only codeine, sulfamethoxazole, and cotinine were detected (carbamazepine also was detected but was not included in the national study). Concentrations of the detected compounds in the two samples were of similar ranges, but neither consistently higher nor lower. Because both samples were collected during the low-flow summer period, upstream sources of these compounds were likely to be similar.

Although storm-related sources may have been more prevalent in the sample from the national study, such sources were not specifically assessed in this study and their importance remains unknown. In any case, the results indicate that the low concentrations and few detections obtained for the Tualatin River sample in this study are not an anomaly. 


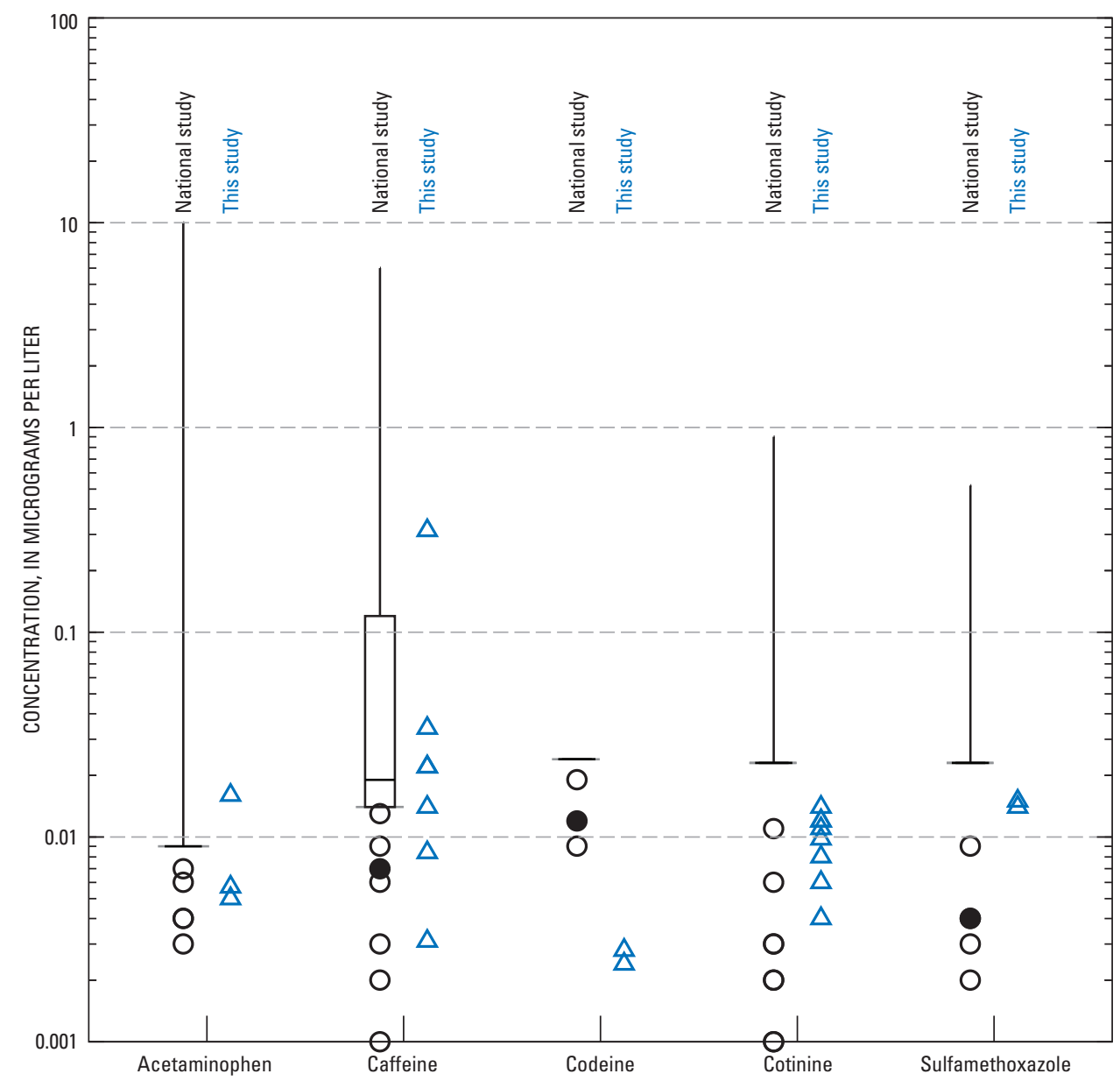

EXPLANATION

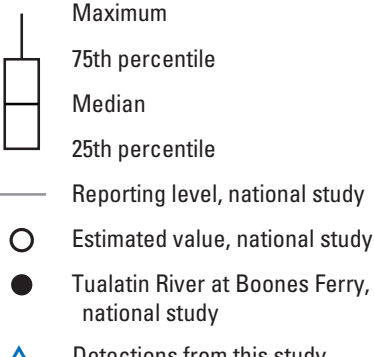

$\triangle \quad$ Detections from this study

Figure 4. Concentrations of pharmaceuticals and metabolites detected in stream and river samples in this study and instream concentrations from a 1999-2000 national study (Barnes and others, 2002). One site in the national study was from the Tualatin River at Boones Ferry Road, a site that also was sampled in this study. The concentration distributions from the national study are truncated at their reporting level, though confirmed detections below the reporting level are shown at their estimated concentrations. If a box is not shown, then the 25th and 75th percentiles are at the reporting level.

Depending on the chemical properties of the target pharmaceuticals, these compounds might be more likely to be found in stream sediment rather than in the overlying water. Nilsen and others (2007) determined that sediment samples collected from streams in the lower Columbia River drainage network do contain trace concentrations of pharmaceutical chemicals. Four of the samples in that study were collected from either Fanno Creek near its confluence with the Tualatin River, or from the Tualatin River near the outfall of the Durham WWTF. Those samples included detections of caffeine, diphenhydramine, thiabendazole, diltiazem, miconazole, trimethoprim, dehydronifedipine, carbamazepine, cotinine, fluoxetine, and codeine, in descending order of detected concentration or frequency. Detected concentrations ranged from about 1 to about $70 \mathrm{ng} / \mathrm{g}$ of sediment. In contrast, only four of these compounds (caffeine, carbamazepine, cotinine, and codeine) were detected in filtered water samples from the same general sampling sites in this study.
The aqueous concentrations of pharmaceutical compounds in this study cannot be compared directly to the sediment-associated concentrations detected by Nilsen and others (2007) because the samples were not collected at the same time or from exactly the same location. Even if collected concurrently from the same site, water samples would reflect conditions at that time, whereas sediment samples (collected at 1-2 cm depth by Nilsen) represent time-integrated processes of accumulation and degradation. Further research is necessary to quantify the concentrations and proportions of these compounds in various media (water, sediment, fish tissue), but it is instructive to make rough comparisons using available data, in the interest of learning more about instream processes. For example, caffeine was detected in water and in sediments from Fanno Creek near its mouth. Aqueous concentrations from this study were roughly $0.02 \mu \mathrm{g} / \mathrm{L}$ (identical to $0.02 \mathrm{ng} / \mathrm{mL}$ or $0.02 \mathrm{ng} / \mathrm{g}$ ), and the sediment-associated concentration measured by Nilsen and others (2007) was about 
$57 \mathrm{ng} / \mathrm{g}$. Given the fact that caffeine is not charged under neutral $\mathrm{pH}$ conditions, and that its octanol-water partition coefficient $\left(\mathrm{K}_{\mathrm{ow}}\right)$ is about 1.0 , nearly equal concentrations of caffeine in water and in the organic component of the sediments would be expected. These data, however, indicate that the phases are not in equilibrium - the aqueous concentration is lower than expected based on the sedimentassociated concentration. Perhaps the caffeine in the aqueous phase is readily degraded or the upstream sources are sufficiently variable that the phases are never in equilibrium. In contrast to caffeine, many pharmaceutical chemicals (such as ibuprofen) have acid-base properties that greatly increase their aqueous solubility under environmentally relevant $\mathrm{pH}$ conditions and decrease the relevance of hydrophobic partitioning to sedimentary organic matter (Wells, 2006). When considering the fate of pharmaceutical chemicals in the environment, it is critical to know how their chemical properties affect their aqueous solubility, bioaccumulation, bio- and photo-degradation, and partitioning to sediments and the atmosphere. More research and sampling is needed to fully understand the presence and fate of pharmaceutical chemicals in Tualatin River basin streams, sediments, and biota.

\section{Effects of Wastewater Treatment}

The highest concentrations of any target analyte in this study were found in the influent sample from the Durham WWTF. Five compounds were detected at concentrations greater than $1 \mu \mathrm{g} / \mathrm{L}$. Caffeine and acetaminophen had the highest concentrations ( 30 and $29 \mu \mathrm{g} / \mathrm{L}$, respectively), followed closely by 1,7-dimethylxanthine $(24 \mu \mathrm{g} / \mathrm{L})$, ibuprofen $(7.6 \mu \mathrm{g} / \mathrm{L})$, and cotinine $(1.5 \mu \mathrm{g} / \mathrm{L})$ (table 4$)$. The presence of these particular pharmaceuticals and metabolites in high concentrations in wastewater is entirely consistent with typical usage rates. Although caffeine is an active ingredient in some medications, the adult per capita consumption rate of caffeine through beverages has been estimated as $320 \mathrm{mg} / \mathrm{d}$ in the United States; no other pharmaceutical in this study has such a high consumption rate (Wilkison and others, 2006).

Furthermore, a national usage survey performed in 1998-99 reported that acetaminophen and ibuprofen were the two most commonly used pharmaceuticals, with caffeine in ninth place, not including the consumption of caffeine in beverages (Kaufman and others, 2002). Despite the high concentrations of these compounds in WWTF influent, 3 of these 5, and 10 of the 15 target compounds detected in WWTF influent, were not detected in samples of the treated WWTF effluent. Only carbamazepine, cotinine, ibuprofen, metformin, and sulfamethoxazole were detected in the effluent (table 4).
The influent and effluent detection data from this study, although from a limited number of samples, can be used to calculate an apparent removal rate of these compounds due to treatment processes occurring in the Durham WWTF, assuming that the compound concentrations detected in influent and effluent are typical. Because WWTFs are efficient at removing particulate material, and because this study analyzed only filtered water samples, these calculated removal rates may be biased low, depending on the water solubility of the target compound. For those compounds that were detected in the influent but not in the effluent, a lower limit on the apparent removal rate can be estimated based on the analytical method detection limit for each compound. For those that were detected in influent and effluent, a percent removal can be computed directly (table 6). Most of the compounds detected in the influent were removed with fairly high efficiency ( $>90$ percent). Ibuprofen and sulfamethoxazole were mostly but incompletely removed ( $>75$ percent), but only a small fraction ( $<20$ percent) of the antiepileptic drug carbamazepine was removed. Results for ibuprofen were somewhat inconsistent because it was detected in only one of two duplicate effluent samples. Results from samples collected before and after filtration in the WWTF showed that filtration was not responsible for the removal of these compounds from the waste stream; most of the removal occurred prior to that treatment step.

Table 6. Apparent removal rates of pharmaceutical compounds from wastewater by the Durham WWTF.

[Results are shown only for the 14 target compounds detected and quantified in Durham WWTF influent. If a compound was not detected in WWTF effluent, the method detection limit was used to compute the apparent removal rate; such instances are denoted with an asterisk $(*)$. >, greater than; $\%$, percent; WWTF, wastewater treatment facility]

\begin{tabular}{lcclc}
\hline \multicolumn{1}{c}{ Compound } & $\begin{array}{c}\text { Apparent } \\
\text { removal }\end{array}$ & & \multicolumn{1}{c}{ Compound } & $\begin{array}{c}\text { Apparent } \\
\text { removal }\end{array}$ \\
\hline Acetaminophen & $>99 \%^{*}$ & & 1,7-Dimethylxanthine & $>99 \%^{*}$ \\
Caffeine & $>99 \%^{*}$ & & Diphenhydramine & $>98 \% *$ \\
Carbamazepine & $18 \%$ & & Fluoxetine & $>82 \% *$ \\
Cimetidine & $>97 \%^{*}$ & & Ibuprofen & $>77 \%$ \\
Codeine & $>98 \%^{*}$ & & Ranitidine & $>98 \% *$ \\
Cotinine & $97 \%$ & & Sulfamethoxazole & $84 \%$ \\
Diltiazem & $>92 \% *$ & & Trimethoprim & $>94 \% *$ \\
\hline
\end{tabular}


Many other studies have evaluated the removal rates of pharmaceuticals from wastewater. Ternes (1998) investigated the occurrence and removal of a suite of pharmaceuticals in German WWTFs, and determined that more than 60 percent of the pharmaceutical residues were removed. Many were not detected in the treated effluent, some such as ibuprofen (90 percent removal) were mostly removed through treatment, and others such as carbamazepine ( 7 percent removal) were only partially removed. Those results for ibuprofen and carbamazepine mirror the results from this study. A 2004 survey of pharmaceuticals in South Korean WWTFs by Han and others (2006) showed similar results for ibuprofen (78 percent removal), but quite different results for carbamazepine (91 percent removal) and acetaminophen (9 percent removal). The type of treatment (primary versus secondary, trickling filter versus activated sludge, with or without nitrification and/or denitrification processes, chlorination versus UV disinfection) and the details of the treatment processes (residence time, etc.) can have an effect on the removal of pharmaceuticals from wastewater (Jones and others, 2005; Phillips and others, 2005).

Samples from the Tualatin River upstream and downstream of the Durham WWTF outfall provide an independent means of assessing the effect of WWTF effluent on the river. Three of the five target analytes detected in WWTF effluent (carbamazepine, cotinine, and sulfamethoxazole) also were detected in the Tualatin River upstream and downstream of the Durham outfall. For those compounds, a mass balance of sorts can be performed. Because the approximate flow in the river upstream of the outfall $\left(171 \mathrm{ft}^{3} / \mathrm{s}\right)$, the flow rate of the effluent (about $24 \mathrm{ft}^{3} / \mathrm{s}$ ), and the flow in Fanno Creek $\left(<5 \mathrm{ft}^{3} / \mathrm{s}\right)$ are known, an expected downstream concentration can be computed. In the case of carbamazepine, the in-river concentration increased from $0.038 \mu \mathrm{g} / \mathrm{L}$ upstream to $0.046 \mu \mathrm{g} / \mathrm{L}$ downstream (table 4), which is consistent with an expected downstream concentration of about $0.052 \mu \mathrm{g} / \mathrm{L}$ based on a mass balance. Similarly consistent results were obtained for cotinine, with upstream and downstream measured concentrations of 0.0098 and $0.014 \mu \mathrm{g} / \mathrm{L}$, versus an expected downstream concentration of $0.016 \mu \mathrm{g} / \mathrm{L}$ based on a mass balance. In-river concentrations of sulfamethoxazole were essentially the same upstream and downstream of the Durham WWTF outfall $(0.015$ and $0.014 \mu \mathrm{g} / \mathrm{L})$, whereas the mass balance produced an expected downstream concentration of $0.017 \mu \mathrm{g} / \mathrm{L}$; given the uncertainty involved in the analyses, these three concentrations are essentially identical. Ibuprofen was not detected in the river samples, perhaps providing evidence to question the detection of ibuprofen in treated effluent, where only one of two duplicate effluent samples showed a detection $(1.77 \mu \mathrm{g} / \mathrm{L})$. If ibuprofen had been present in treated effluent at a concentration of $1.77 \mu \mathrm{g} / \mathrm{L}$, then the in-river downstream concentration should have been easily detected at an estimated concentration of $0.2 \mu \mathrm{g} / \mathrm{L}$, which is 10 times higher than the method detection limit. The laboratory analytical method used in this study was not, perhaps, the best method for quantifying ibuprofen concentrations; new analytical methods for ibuprofen and other acidic pharmaceutical chemicals are under development.

In-river concentrations of carbamazepine and cotinine upstream of the Durham WWTF outfall (Tualatin River at Cook Park, site 9) can be shown to be consistent with the presence of a large WWTF source upstream of that location. The Rock Creek WWTF discharges treated effluent to the Tualatin River about 28 mi upstream of Cook Park, and the travel time from the WWTF outfall to Cook Park was about 6-8 days under the flow conditions that occurred in late July 2002. For all of the carbamazepine in the Tualatin River at Cook Park to have come from the Rock Creek WWTF, the effluent flow rate from that facility would have to be about $41 \mathrm{ft}^{3} / \mathrm{s}$, assuming its carbamazepine concentration was identical to that in Durham WWTF effluent and assuming no instream degradation during the travel time to Cook Park. The measured Rock Creek WWTF effluent flow rate for that time period was about $39 \mathrm{ft}^{3} / \mathrm{s}$. A similar calculation for cotinine only required that the Rock Creek WWTF effluent flow rate be at least $34 \mathrm{ft}^{3} / \mathrm{s}$, and sources of cotinine from other urban streams such as Rock Creek certainly were present. It is likely, therefore, that concentrations of carbamazepine and cotinine in the Tualatin River upstream of the Durham WWTF outfall primarily are from the Rock Creek WWTF. Similar calculations for sulfamethoxazole reveal that the Rock Creek WWTF probably is an important source of that compound to the river, but it may not be the only source upstream of Cook Park unless the concentration of sulfamethoxazole in Rock Creek WWTF effluent was higher than the concentration in Durham WWTF effluent.

The ecotoxicological risk of carbamazepine to selected aquatic species has been studied by several research groups. Han and others (2006) studied the effects of several pharmaceutical chemicals on daphnia magna, a common planktonic crustacean, and determined that the typical concentrations of pharmaceuticals downstream of South Korean WWTFs were low enough that no appreciable risk existed. Indeed, the LC50 (concentration lethal to 50 percent of test organisms) for carbamazepine cited in that research is $111 \mathrm{mg} / \mathrm{L}$, about 2,400 times higher than the concentration detected in Tualatin River samples. A safety factor of 1,000 typically is applied in their analyses, indicating that the concentrations found in this study may not pose a significant ecological risk to this particular test organism. Related research by Kim and others (2007) showed little risk by carbamazepine to daphnia magna or to a test fish species. They reported potential concern for effects from acetaminophen and sulfamethoxazole, but the exposure concentrations they used were more than 60 times higher than those found in Tualatin River samples; the lower concentrations measured in this study would push the risk below their hazard thresholds. Another study by Oetken and others (2005) investigated the effect of carbamazepine on 
an oligochaete, a midge, and a freshwater snail species. The aquatic testing in that study indicated that the concentrations found in the Tualatin River would not pose a threat to these species. In general, insufficient data exist to completely ascertain the ecological risk of pharmaceutical chemicals to species that reside in the Tualatin River and its tributaries, but limited data for compounds such as carbamazepine, acetaminophen, and sulfamethoxazole suggest that the acute ecological risk under normal low-flow conditions is low. Although pharmaceutical chemical concentrations normally might be low in the Tualatin River, accidental releases or spills of sewage could greatly increase their instream concentrations and their associated ecological risk. In addition, low-level chronic exposure to those pharmaceutical chemicals that can act as endocrine disrupters could lead to a harmful ecological effect, but such an effect cannot yet be assessed.

\section{Use of Pharmaceutical Chemicals as Tracers of Human-Related Stream Contamination}

Although the analysis of samples for pharmaceutical chemicals is expensive, the cost might be justified if one or more of the compounds proved to be a good tracer for specific sources of stream contamination. Results from previous studies indicate that caffeine and selected pharmaceuticals may be useful as confirmatory evidence of contamination, if not sufficient as primary evidence (Seiler and others, 1999; Verstraeten and others, 2005). Caffeine also has been proposed as an ideal tracer for certain types of sewage-related contamination of streams because of its high concentration in human waste and the absence of substantive natural sources (Ferreira, 2005; Wu and others, 2008). Unless the sewage-related stream contamination is large, however, the use of caffeine as a source indicator is limited because trace concentrations of caffeine appear to be common in urban streams. Indeed, caffeine was universally present in urban stream samples in this study at concentrations generally greater than $0.01 \mu \mathrm{g} / \mathrm{L}$. That concentration is fairly easy to achieve with only a few spills of coffee, although other sources also may be present. For example, if coffee has a caffeine concentration of $350 \mathrm{mg} / \mathrm{L}$ (Seiler and others, 1999), and a stream such as Fanno Creek has a flow of about $4 \mathrm{ft}^{3} / \mathrm{s}$, then a caffeine concentration of $0.01 \mu \mathrm{g} / \mathrm{L}$ in the stream represents a spill of only 1 ounce of coffee residue that is completely mixed into the stream every 2.5 hours. A 1 -ounce coffee spill need only mix into 5 minutes worth of the stream's flow to achieve the highest concentration measured in this study $(0.314 \mu \mathrm{g} / \mathrm{L})$, a dilution level that is certainly possible, although perhaps unlikely. To use caffeine as an effective tracer for a sewer leak, the leak would have to be large enough to produce caffeine concentrations higher than a few tenths of a microgram per liter. At that level, a different indicator such as coliform bacteria or an optical brightener might prove to be less ambiguous, faster to analyze, and more cost-effective.
Although caffeine might be used only as a general tracer for mixed sources of human-related stream contamination, or as a tracer for large sewer leaks, compounds like acetaminophen, carbamazepine, and sulfamethoxazole might be useful as tracers under some circumstances. These compounds (a common analgesic, an antiepileptic drug, and an antibiotic, respectively) are unlikely to be detected in streams unless a human-related or veterinary source is present. Such a source could be a leaking sewer line, a failing septic system, illicit or unpermitted dumping, or a storm-sewer/ sanitary-sewer cross connection. In the presence of one of these sources, the instream concentration of acetaminophen ought to be easily measurable, given its high concentration in municipal wastewater $(29 \mu \mathrm{g} / \mathrm{L}$; table 4$)$. Instream concentrations of carbamazepine and sulfamethoxazole might be lower than that of acetaminophen, at least in untreated sewage, but these compounds are not completely removed by wastewater treatment, so they could be used as tracers of either raw or treated wastewater sources. Carbamazepine has been proposed previously as a marker for human wastewater (Clara and others, 2004). In separate research, Glassmeyer and others (2005) suggested that pharmaceutical chemicals such as carbamazepine, diphenhydramine, and caffeine might be good indicators of the presence of human wastewater. Guo and Krasner (2009) recently determined that carbamazepine and primidone may be used as indicators of upstream wastewater sources. The data derived from this Tualatin River basin reconnaissance show that several of these pharmaceutical compounds might make good tracers for human-related contamination of streams under some circumstances, but that additional research and sampling are needed to further evaluate their potential use as tracers.

\section{Summary and Conclusions}

A reconnaissance of pharmaceutical chemicals and metabolites in urban streams and an advanced wastewater treatment facility was conducted on the west side of the Portland, Oregon, metropolitan area during low-flow conditions in July of 2002. Filtered water samples were analyzed for 21 target analytes using a solid-phaseextraction procedure followed by high-performance liquid chromatography and mass spectrometric detection. Only 6 of the target compounds were detected in the 10 stream or river sites that were sampled. Among the urban stream sites, the only compounds detected were cotinine (a metabolite of nicotine), caffeine, and acetaminophen. The highest concentration in any stream or river sample was for caffeine in Fanno Creek at $0.314 \mu \mathrm{g} / \mathrm{L}$, but the next highest concentration was almost an order of magnitude lower at $0.046 \mu \mathrm{g} / \mathrm{L}$ for carbamazepine in the Tualatin River downstream of two wastewater treatment facility outfalls. All compound concentrations measured in this study were consistent with the range of concentrations reported in a 1999-2000 national 
survey of pharmaceutical compounds in United States streams by USGS, but maximum concentrations in this study were about an order of magnitude or more lower. Although this study is only a reconnaissance for the occurrence and concentrations of selected pharmaceuticals in Tualatin River basin streams, it appears that few pharmaceuticals are present in these streams, and when present, their concentrations are low. Furthermore, limited literature data suggest that the dry-weather concentrations of some compounds detected in this study are not high enough to be of ecological concern. Insufficient information is available, however, to fully assess the true ecological risk, including those associated with stormrelated conditions and potential spills or accidental releases.

Fifteen pharmaceuticals and metabolites were detected in untreated municipal wastewater, but most were efficiently removed through treatment. Only five compounds were detected in treated effluent from the Durham treatment facility (carbamazepine, cotinine, ibuprofen, metformin, and sulfamethoxazole), and two of those (ibuprofen and metformin) were detected in only one of two duplicate effluent samples. Of these compounds, only carbamazepine is somewhat resistant to removal through wastewater treatment, with an apparent removal of only 18 percent; all other detected compounds had at least a 77 percent estimated removal rate. The apparent removal rates determined in this study are consistent with some previous studies of pharmaceutical chemicals in wastewater treatment facilities, although published studies differ widely on the removal rates of carbamazepine and acetaminophen. Results indicate that wastewater treatment facilities are the primary sources of the low concentrations of carbamazepine and cotinine measured in Tualatin River samples. Published research indicates that the dry-weather concentrations of carbamazepine, acetaminophen, and sulfamethoxazole found in Tualatin River basin samples are unlikely to be toxic to the several plankton and freshwater snail species used as test organisms.

Several of the pharmaceutical chemicals and metabolites included in this study, either singly or in combination, show some potential to be useful tracers of human-related contamination of streams. Although caffeine and cotinine appear to be good indicators of a wide variety of sources that can occur in urban areas, they are not good indicators of any single sewage-related source, for example, unless that source is large enough to overcome the smaller background sources. If present along with caffeine, 1,7-dimethylxanthine (a caffeine metabolite) might indicate the presence of untreated wastewater; in contrast, the absence of the metabolite might help rule out a wastewater source, treated or untreated, because caffeine and 1,7-dimethylxanthine are effectively removed via wastewater treatment. Acetaminophen, carbamazepine, and sulfamethoxazole show some potential as tracers for specific types of contamination, either because of high concentrations in raw wastewater (acetaminophen) or because of incomplete removal by wastewater treatment (carbamazepine, sulfamethoxazole). Ibuprofen also has a high concentration in raw wastewater and potentially incomplete removal in wastewater treatment, but is not an ideal candidate because the analytical test method used in this study gave imprecise results for this compound. Additional research is needed to fully determine the potential value of these or other pharmaceutical chemicals and metabolites as tracers for stream contamination. Other potential tracers such as optical brighteners, fragrance compounds, and surfactants also merit further consideration.

\section{Acknowledgments}

This study was performed as part of a long-term scientific collaboration between the U.S. Geological Survey (USGS) and Clean Water Services. We appreciate the assistance and cooperation of Rob Baur and other staff at the Durham Wastewater Treatment Facility in providing access, information, and water samples. Jan Miller of Clean Water Services helped coordinate the study. Helpful comments on this report were provided by reviewers from USGS (Elena Nilsen, Jennifer Morace, Don Wilkison, Greg Fuhrer) and Clean Water Services (Jan Miller, Bob Baumgartner, Rajeev Kapur).

\section{References Cited}

\author{
Barnes, K.K., Kolpin, D.W., Furlong, E.T., Zaugg, S.D., \\ Meyer, M.T., and Barber, L.B., 2008, A national \\ reconnaissance of pharmaceuticals and other organic \\ wastewater contaminants in the United States-I) \\ Groundwater: Science of the Total Environment, v. 402, \\ no. 2-3, p. 192-200.
}

Barnes, K.K., Kolpin, D.W., Meyer, M.T., Thurman, M., Furlong, E.T., Zaugg, S.D., and Barber, L.B., 2002, Waterquality data for pharmaceuticals, hormones, and other organic wastewater contaminants in U.S. streams, 19992000: U.S. Geological Survey Open-File Report 02-94, 7 p. plus tables.

Bedner, M., and MacCrehan, W.A., 2006, Transformation of acetaminophen by chlorination produces the toxicants 1,4-benzoquinone and $\mathrm{N}$-acetyl- $p$-benzoquinone imine: Environmental Science and Technology, v. 40, p. 516-522.

Bonn, B., 2008a, Tualatin River flow management technical committee annual data report for 2007: Clean Water Services and Oregon Water Resources Department, accessed November 21, 2008, at http://www.co.washington. or.us/Watermaster/SurfaceWater/upload/FlowReport2007. pdf. 
Bonn, B.A., 2008b, Using the U.S. Geological Survey National Water Quality Laboratory LT-MDL to evaluate and analyze data: U.S. Geological Survey Open-File Report 2008-1227, 73 p.

Buerge, I.J., Poiger, T., Müller, M.D., and Buser, H-R., 2003, Caffeine, an anthropogenic marker for wastewater contamination of surface waters: Environmental Science and Technology, v. 37, p. 691-700.

Buser, H-R., Müller, M.D., and Theobald, N., 1998, Occurrence of the pharmaceutical drug clofibric acid and the herbicide mecoprop in various Swiss lakes and in the North Sea: Environmental Science and Technology, v. 32, p. $188-192$.

Cahill, J.D., Furlong, E.T., Burkhardt, M.R., Kolpin, D.W., and Anderson, L.G., 2004, Determination of pharmaceutical compounds in surface- and ground-water samples by solid-phase extraction and high-performance liquid chromatography/electrospray ionization mass spectrometry: Journal of Chromatography A, v. 1041, p. 171-180.

Calamari, D., Zuccato, E., Castiglioni, S., Bagnati, R., and Fanelli, R., 2003, Strategic survey of therapeutic drugs in the rivers Po and Lambro in northern Italy: Environmental Science and Technology, v. 37, p. 1241-1248.

Childress, C.J.O., Foreman, W.T., Connor, B.F., and Maloney, T.J., 1999, New reporting procedures based on long-term method detection levels and some considerations for interpretations of water-quality data provided by the U.S. Geological Survey National Water Quality Laboratory: U.S. Geological Survey Open-File Report 99-193, 19 p.

Clara, M., Strenn, B., and Kreuzinger, N., 2004, Carbamazepine as a possible anthropogenic marker in the aquatic environment: Investigations on the behaviour of carbamazepine in wastewater treatment and during groundwater infiltration: Water Research, v. 38, no. 4, p. $947-954$.

Clean Water Services, 2002, Durham wastewater treatment facility brochure: accessed April 6, 2009, at http://www. cleanwaterservices.org/content/documents/About\%20Us/ Durham\%20Brochure.pdf.

Daughton, C.G., and Ternes, T.A., 1999, Pharmaceuticals and personal care products in the environment: Agents of subtle change?: Environmental Health Perspectives, v. 107, Supplement 6, p. 907-938.

Edwards, T.K., and Glysson, G.D., 1999, Field methods for measurement of fluvial sediment: U.S. Geological Survey Techniques of Water-Resources Investigations, book 3, chap. C2, 89 p.
Ferreira, A.P., 2005, Caffeine as an environmental indicator for assessing urban aquatic ecosystems: Cadernos de Saúde Pública, v. 21, no. 6, p. 1884-1892.

Furlong, E.T., Werner, S.L., Anderson, B.D., and Cahill, J.D., 2008, Determination of human-health pharmaceuticals in filtered water by chemically modified styrenedivinylbenzene resin-based solid-phase extraction and highperformance liquid chromatography/mass spectrometry: U.S. Geological Survey Techniques and Methods, book 5, sec. B, chap. B5, 56 p.

Gagné, F., Blaise, C., and André, C., 2006, Occurrence of pharmaceutical products in a municipal effluent and toxicity to rainbow trout (Oncorhynchus mykiss) hepatocytes: Ecotoxicology and Environmental Safety, v. 64, p. 329-336.

Glassmeyer, S.T., Furlong, E.T., Kolpin, D.W., Cahill, J.D., Zaugg, S.D., Werner, S.L., Meyer, M.T., and Kryak, D.D., 2005, Transport of chemical and microbial compounds from known wastewater discharges: Potential for use as indicators of human fecal contamination: Environmental Science and Technology, v. 39, p. 5157-5169.

Guerreiro, S., Toulorge, D., Hirsch, E., Marien, M., Sokoloff, P., and Michel, P., 2008, Paraxanthine - the primary metabolite of caffeine - provides protection against dopaminergic cell death via stimulation of ryanodine receptor channels: Molecular Pharmacology, v. 74, no. 4, p. $980-989$.

Guo, Y.C., and Krasner, S.W., 2009, Occurrence of primidone, carbamazepine, caffeine, and precursors for $\mathrm{N}$-nitrosodimethylamine in drinking water sources impacted by wastewater: Journal of the American Water Resources Association, v. 45, no. 1, p. 58-67.

Halling-Sørensen, B., Nors Nielsen, S., Lanzky, P.F., Ingerslev, F., Holten Lützhøft, H.C., and Jørgensen, S.E., 1998, Occurrence, fate and effects of pharmaceutical substances in the environment - A review: Chemosphere, v. 36, no. 2, p. 357-393.

Han, G.H., Hur, H.G., and Kim, S.D., 2006, Ecotoxicological risk of pharmaceuticals from wastewater treatment plants in Korea-Occurrence and toxicity to Daphnia magna: Environmental Toxicology and Chemistry, v. 25, no. 1, p. 265-271.

Hinkle, S.R., Weick, R.J., Johnson, J.M., Cahill, J.D., Smith, S.G., and Rich, B.J., 2005, Organic wastewater compounds, pharmaceuticals, and coliphage in groundwater receiving discharge from onsite wastewater treatment systems near La Pine, Oregon-Occurrence and implications for transport: U.S. Geological Survey Scientific Investigations Report 2005-5055, $98 \mathrm{p}$. 
Homer, C., Dewitz, J., Fry, J., Coan, M., Hossain, N., Larson, C., Herold, N., McKerrow, A., VanDriel, J.N., and Wickham, J., 2007, Completion of the 2001 National Land Cover Database for the conterminous United States: Photogrammetric Engineering and Remote Sensing, v. 73, no. 4, p. 337-341.

Jones, O.A.H., Voulvoulis, N., and Lester, J.N., 2005, Human pharmaceuticals in wastewater treatment processes: Critical Reviews in Environmental Science and Technology, v. 35, p. $401-427$.

Karthikeyan, K.G., and Meyer, M.T., 2006, Occurrence of antibiotics in wastewater treatment facilities in Wisconsin, USA: Science of the Total Environment, v. 361, p. 196-207.

Kaufman, D.W., Kelly, J.P., Rosenberg, L., Anderson, T.E., and Mitchell, A.A., 2002, Recent patterns of medication use in the ambulatory adult population of the United States: Journal of the American Medical Association, v. 287, no. 3, p. 337-344.

Kim, Y., Choi, K., Jung, J., Park, S., Kim, P., and Park, J., 2007, Aquatic toxicity of acetaminophen, carbamazepine, cimetidine, diltiazem and six major sulfonamides, and their potential ecological risks in Korea: Environment International, v. 33, no. 3, p. 370-375.

Kolpin, D.W., Furlong, E.T., Meyer, M.T., Thurman, E.M., Zaugg, S.D., Barber, L.B., and Buxton, H.T., 2002, Pharmaceuticals, hormones, and other organic wastewater contaminants in U.S. streams, 1999-2000-A national reconnaissance: Environmental Science and Technology, v. 36, p. 1202-1211.

Kolpin, D.W., Skopec, M., Meyer, M.T., Furlong, E.T., and Zaugg, S.D., 2004, Urban contribution of pharmaceuticals and other organic wastewater contaminants to streams during differing flow conditions: Science of the Total Environment, v. 328, p. 119-130.

Lewis, M.E., and Zaugg, S.D., 2003, Wastewater, pharmaceutical, and antibiotic compounds, in Wilde, F.D., and Radtke, D.B., eds., National field manual for the collection of water-quality data: U.S. Geological Survey Techniques of Water-Resources Investigations, book 9, chap. A5, part 5.6.1.F, accessed November 21, 2008, at http://pubs.water.usgs.gov/twri9A5/.

Löffler, D., Römbke, J., Meller, M., and Ternes, T.A., 2005, Environmental fate of pharmaceuticals in water/sediment systems: Environmental Science and Technology, v. 39, p. 5209-5218.
Nilsen, E.B., Rosenbauer, R.R., Furlong, E.T., Burkhardt, M.R., Werner, S.L., Greaser, L., and Noriega, M., 2007, Pharmaceuticals, personal care products and anthropogenic waste indicators detected in streambed sediments of the lower Columbia River and selected tributaries: Costa Mesa, CA, 6th International Conference on Pharmaceuticals and Endocrine Disrupting Chemicals in Water, National Ground Water Association, Paper 4483, p. 15.

Oetken, M., Nentwig, G., Löffler, D., Ternes, T., and Oehlmann, J., 2005, Effects of pharmaceuticals on aquatic invertebrates, Part I, The antiepileptic drug carbamazepine: Archives of Environmental Contamination and Toxicology, v. 49 , p. $353-361$.

Phillips, P.J., Stinson, B., Zaugg, S.D., Furlong, E.T., Kolpin, D.W., Esposito, K.M., Bodniewicz, B., Pape, R., and Anderson, J., 2005, A multi-disciplinary approach to the removal of emerging contaminants in municipal wastewater treatment plants in New York State, 2003-2004: Washington DC, Proceedings of the Water Environment Federation WEFTEC $78^{\text {th }}$ Annual Technical Exhibition and Conference, November 2005, p. 5095-5124.

Sankararamakrishnan, N., and Guo, Q., 2005, Chemical tracers as indicator of human fecal coliforms at storm water outfalls: Environment International, v. 31, p. 1133-1140.

Seiler, R.L., Zaugg, S.D., Thomas, J.M., and Howcroft, D.L., 1999, Caffeine and pharmaceuticals as indicators of waste water contamination in wells: Ground Water, v. 37, no. 3, p. 405-410.

Shelton, L.R., 1994, Field guide for collecting and processing stream-water samples for the National Water-Quality Assessment Program: U.S. Geological Survey Open-File Report 94-455, $42 \mathrm{p}$.

Standley, L.J., Kaplan, L.A., and Smith, D., 2000, Molecular tracers of organic matter sources to surface water resources, Environmental Science and Technology, v. 34, p. 3124 3130 .

Stoeckel, D.M., Mathes, M.V., Hyer, K.E., Hagedorn, C., Kator, H., Lukasik, J., O’Brien, T.L., Fenger, T.W., Samadpour, M., Strickler, K.M., and Wiggins, B.A., 2004, Comparison of seven protocols to identify fecal contamination sources using Escherichia coli: Environmental Science and Technology, v. 38, p. 61096117.

Ternes, T.A., 1998, Occurrence of drugs in German sewage treatment plants and rivers: Water Research, v. 32, no. 11, p. $3245-3260$. 
Ternes, T.A., Joss, A., and Siegrist, H., 2004, Scrutinizing pharmaceuticals and personal care products in wastewater treatment: Environmental Science and Technology, v. 38, no. 20 , p. 393A-399A.

The Merck Index-an encyclopedia of chemicals, drugs, and biologicals, 1989, (11th ed.): Rahway, N.J., Merck, 1 v. [variously paged].

U.S. Census Bureau, 2006, State and County QuickFacts: accessed November 21, 2008, at http://quickfacts.census. gov/qfd/states/41/41067.html.

Verstraeten, I.M., Fetterman, G.S., Meyer, M.T., Bullen, T., and Sebree, S.K., 2005, Use of tracers and isotopes to evaluate vulnerability of water in domestic wells to septic waste: Ground Water Monitoring and Remediation, v. 25, no. 2, p. 107-117.

Wells, M.J.M., 2006, Log $\mathrm{D}_{\mathrm{OW}}$ : Key to understanding and regulating wastewater-derived contaminants: Environmental Chemistry, v. 3, p. 439-449.

Wilde, F.D., Radtke, D.B., Gibs, J., and Iwatsubo, R.T., eds., 2004, Processing of water samples (version 2.1), in Wilde, F.D., and Radtke, D.B., eds., National field manual for the collection of water-quality data: U.S. Geological Survey Techniques of Water-Resources Investigations, book 9, chap. A5, accessed November 21, 2008, at http://pubs.water. usgs.gov/twri9A5/
Wilkison, D.H., Armstrong, D.J., Norman, R.D., Poulton, B.C., Furlong, E.T., and Zaugg, S.D., 2006, Water quality in the Blue River basin, Kansas City metropolitan area, Missouri and Kansas, July 1998 to October 2004: U.S. Geological Survey Scientific Investigations Report 2006$5147,170 \mathrm{p}$.

Wilson, B.A., Smith, V.H., Denoyelles Jr., F., and Larive, C.K., 2003, Effects of three pharmaceutical and personal care products on natural freshwater algae assemblages: Environmental Science and Technology, v. 37, p. 17131719.

Wu, J., Yue, J., Hu, R., Yang, Z., and Zhang, L., 2008, Use of caffeine and human pharmaceutical compounds to identify sewage contamination: Proceedings of World Academy of Science, Engineering and Technology, v. 34, 438-442. 
Publishing support provided by the U.S. Geological Survey Publishing Network, Tacoma Publishing Service Center

For more information concerning the research in this report, contact the Director, Oregon Water Science Center U.S. Geological Survey 2130 SW 5th Avenue Portland, Oregon 97201 http://or.water.usgs.gov 

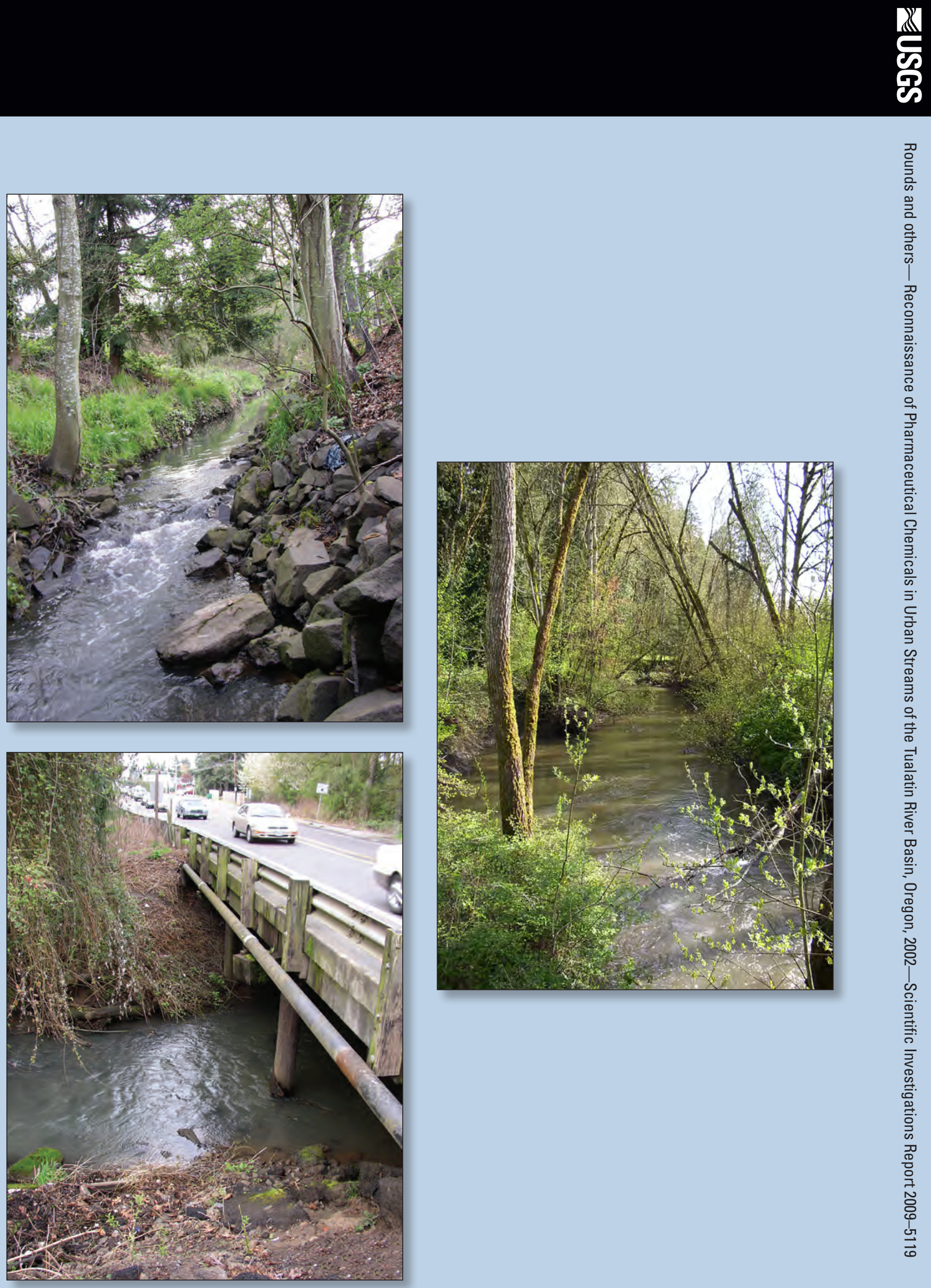

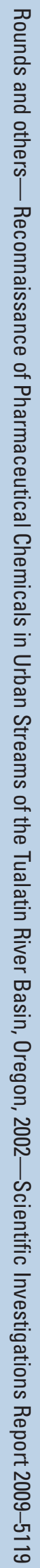

